\title{
Preparation and Characterization of Di-, Tri-, and Tetranuclear Schiff Base Complexes Derived from Diamines and 3,4-Dihydroxybenzaldehyde
}

\author{
Ahlam Jameel Abdulghani and Asmaa Mohammed Noori Khaleel \\ Department of Chemistry, College of Science, University of Baghdad, Jaderiya, Baghdad, Iraq \\ Correspondence should be addressed to Ahlam Jameel Abdulghani; prophahlam@yahoo.com
}

Received 29 July 2013; Revised 24 September 2013; Accepted 25 September 2013

Academic Editor: Spyros Perlepes

Copyright ( 2013 A. J. Abdulghani and A. M. N. Khaleel. This is an open access article distributed under the Creative Commons Attribution License, which permits unrestricted use, distribution, and reproduction in any medium, provided the original work is properly cited.

\begin{abstract}
A series of new di-, tri-, and tetranuclear $\mathrm{Co}(\mathrm{II})$ and $\mathrm{Cu}(\mathrm{II})$ complexes of three new diSchiff base ligands were synthesized by two different methods. The first method involved the synthesis of the three ligands from condensation reaction of 3,4dihydroxybenzaldehyde $\left(\mathrm{L}^{\prime} \mathrm{H}_{2}\right)$ with ethylenediamine (en), o-phenylenediamine (o-PD), or 4,5-dimethyl-1,2-phenylendiamine (DMPD) in a mole ratio of 2:1 followed by the reaction of the resulting Schiff bases ligands with $\mathrm{Cu}$ (II) or $\mathrm{Co}$ (II) ions in the presence of $2,2^{\prime}$-bipyridyl (L) to form the di- and trinuclear metal complexes. The second method involved the condensation of the copper complex $\mathbf{L C u}(\mathrm{II}) \mathbf{L}^{\prime}\left(\mathrm{L}=2,2^{\prime}\right.$-bipyridyl, $\mathrm{L}^{\prime}=4$-formylbenzene-1,2-bis(olate)) with en, o-PD, or DMPD in a mole ratio of $2: 1$, respectively, followed by reaction with $\mathrm{CuCl}_{2}$ or $\mathrm{Cu}\left(\mathrm{ClO}_{4}\right)_{2}$ to form di-, tri-, and tetranuclear copper (II) complexes, respectively. The structures of the ligands and metal complexes were characterized by elemental analyses, NMR, and FTIR spectra. The geometries of metal complexes were suggested according to elemental analysis, electronic spectra, thermal analyses, atomic absorption, and magnetic moments and conductivity measurements.
\end{abstract}

\section{Introduction}

Multinuclear transition metal complexes have become a central theme of current research because of their potentially useful properties. They are involved in some notable catalytic processes. Their important use for modelling the metal active sites of metalloproteins and their recent applications in the area of nanoscale materials have drawn the focal point of attraction of modern chemists towards the synthesis and characterization of such metal complexes [1]. A number of dinuclear complexes from various types of ligand systems have been prepared and examined in terms of their oxygen uptake or redox processes of oxygen, their catalytic activity, and their antibacterial and antifungal activities [2-4]. One of the synthetic strategies to prepare polynuclear transition metal complexes is the use of simple metal ion complexes which have the appropriate functionality to act as ligands for another metal ion [1]. There is currently a great deal of interest in the synthesis and characterization of polynuclear cobalt, nickel, and copper complexes due to their wide-ranging potential applications such as catalysts, electron transfer mediators in dye-sensitized solar cells, antiviral agents, and molecular nanomagnets [5]. Trinuclear cobalt complexes draw their speciality from their use as catalysts in epoxidation of olefins and in the autoxidation of hydrocarbons [1]. The presence of copper (II) ion in polynuclear complexes has received a wide interest in the fields of (i) the magnetostructural relationship, (ii) the characterization of active sites in multicopper proteins [5], and (iii) biological activity such as antitumor, antiviral, and anti-inflammatory [5]. Schiff bases derived from 3,4-dihydroxybenzaldehyde $[3,4]$ and diamines like ethylene diamine [5], 2,6-diaminopyridine [2], and 1,4-diaminobenzene $[3,4]$ represent an important series of chelating agents that have been used to synthesize mono-, di-, or polynuclear transition metal complexes [3-5] in which copper (II) complexes in particular represent models of physical and chemical behavior of biological copper systems that mimic copper metalloproteins such as hemocyanin 


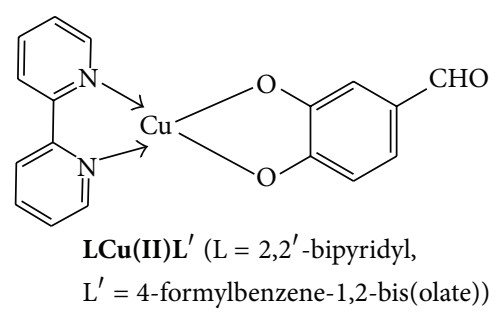

FIGURE 1<smiles>Oc1ccc(/C=N/CC/N=C/c2ccc(O)c(O)c2)cc1O</smiles>

$\mathrm{N}, \mathrm{N}^{\prime}$-Bis(3,4-dihydroxybenzylidene)ethan1,2-diamine $\left(\mathrm{EDH}_{4}\right)$

FIGURE 2

and tyrosinase $[2,5]$. Much attention has been paid to the synthesis and properties of molecules containing the copper (II) complex of 1,10-phenanthroline and 2,2' -bipyridyl units $[2,5-8]$ which are useful for applications in several fields.

For example, a $\pi$-conjugated polymer bearing $2,2^{\prime}$ bipyridyl units was found to serve as a unique electrically conducting polymer complex with transition metals such as $\mathrm{Ru}, \mathrm{Ni}$, and Fe [6-8]. Nickel (II) mixed ligand complexes involving an aromatic Schiff base and 1,10-phenanthroline showed higher cytotoxic activity than those of the individual ligands [7]. The copper (II) complex of 1,10-phenanthroline was the first synthetic transition metal complex effectively exhibiting nucleolytic activity [5]. In this work, we study for the first time the synthesis of di- and trinuclear copper (II) and cobalt (II) complexes as synthetic models for multicenter active sites of biological systems by following two methods. The first method (method 1) involves the reaction of metal salts with each of the following three new diSchiff base ligands: $\mathrm{N}, \mathrm{N}^{\prime}$-bis(3,4-dihydroxybenzylidene)ethan1,2-diamine $\left(\mathrm{EDH}_{4}\right)$ (Figure 2), N,N'-bis(3,4-dihydroxybenzylidene)benzene-1,2-diamine $\left(\mathbf{P D H}_{4}\right)$ (Figure 3), and N,N'-bis(3,4-dihydroxybenzylidene)-4,5-dimethyl-1,2diamine $\left(\mathbf{M P D H}_{4}\right)$ (Figure 4$)$ prepared from the condensation reaction of 3,4-dihydroxybenzaldehyde with ethylenediamine (en), o-phenylenediamine (o-PD), or 4,5-dimethyl1,2-phenylendiamine (DMPD), respectively. The second method (method 2) involves the condensation reaction of mononuclear copper (II) mixed ligand complex of 3,4dihydroxybenzaldehyde and 2,2'-bipyridyl ( $\left.\mathbf{L C u}(\mathbf{I I}) \mathbf{L}^{\prime}\right)$ (Figure 1) (L = 2,2'-bipyridyl, $\mathrm{L}^{\prime}=4$-formylbenzene1,2-bis(olate)) with (en), o-PD, or DMPD followed by further reaction with the metal salts to form the tri- and tetrahomonuclear metal complexes.

The structures of the prepared compounds were elucidated depending on elmental analyses, Uv-vis, NMR, and FTIR spectra as well as, thermal analyses, atomic absorption,<smiles>Oc1ccc(/C=N/c2ccccc2/N=C/c2ccc(O)c(O)c2)cc1O</smiles>

$\mathrm{N}, \mathrm{N}^{\prime}$-Bis(3,4-dihydroxybenzylidene)benzene1,2-diamine $\left(\mathbf{P D H}_{4}\right)$

Figure 3<smiles>Cc1cc(/N=C/c2ccc(O)c(O)c2)c(/N=C/c2ccc(O)c(O)c2)cc1C</smiles>

N,N'-Bis(3,4-dihydroxybenzylidene)4,5-dimethyl1,2-diamine $\left(\mathbf{M P D H}_{4}\right)$

Figure 4

conductivity measurements, and magnetic susceptibility of metal complexes.

\section{Experimental}

2.1. Materials and Methods. All chemicals were of reagent grade and were used as received except o-phenylenediamine and ethanol which were purified and dried as reported previously $[9,10]$. Melting points (uncorrected) were determined on Gallenkamp M.F.B 600-010f melting point apparatus.

The elemental analyses were performed on Eurovector EA 3000A. ${ }^{1} \mathrm{HNMR}$ and ${ }^{13} \mathrm{CNMR}$ were carried out by using Bruker UltraShield $300 \mathrm{MHz}$ NMR spectrophotometer. FTIR spectra were recorded as $\mathrm{KBr}$ and CsI discs using Shimadzu FTIR-8400S, Fourier Transform Infrared spectrophotometer. The electronic spectra were recorded in DMF on Shimadzu Uv-visible-160 Spectrophotometer. Thermal analyses (TG \& DTG) were carried out under nitrogen atmosphere by using Netzsch Sat $409 \mathrm{PG} / \mathrm{PC}$ at a heating rate of $20^{\circ} \mathrm{C} / \mathrm{min}$ under nitrogen atmosphere over a temperature range of $25-1000^{\circ} \mathrm{C}$. The metal contents of the complexes were determined by atomic absorption technique using Varian-AA 775 Atomic Absorption spectrophotometer. Electrical conductivity measurements for complexes $\left(10^{-3} \mathrm{M}\right)$ in DMF at room temperature were carried out by using Hunts Capacitors Trade Mark British made conductivity meter. Magnetic moment ( $\mu_{\text {eff }}$ B.M) for the prepared complexes was measured at room temperature by using Bruker Magnet B.M-6. 


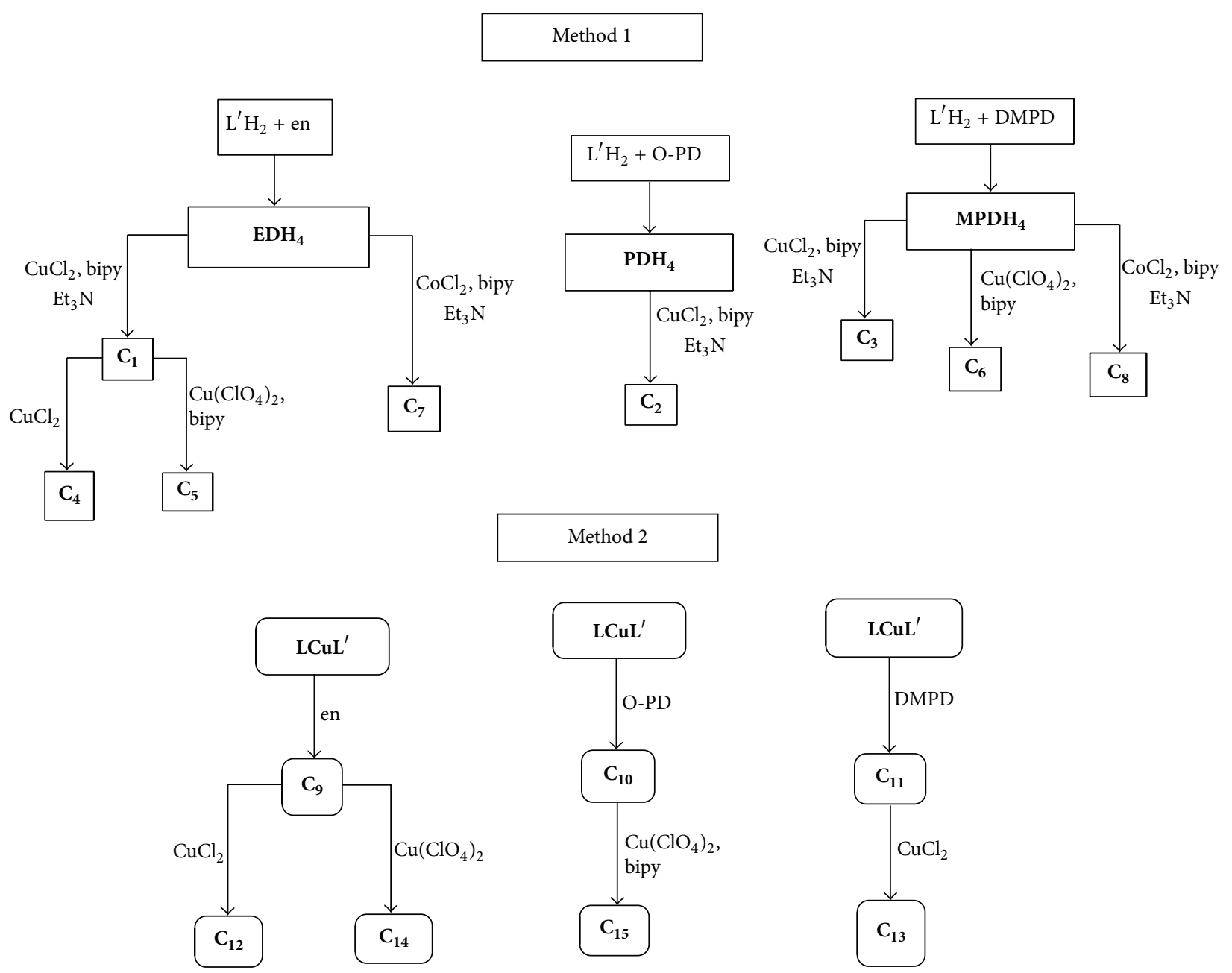

SCHeme 1: The synthesis routes of the studied metal complexes by two different methods.

\subsection{Preparation Methods}

\subsubsection{Method 1}

Synthesis of Schiff Bases $\mathbf{E D H}_{4}, \mathbf{P D H}_{4}$, and $\mathbf{M P D H}_{4}$ : General Procedure. To a solution of diamine (0.0217, 0.0391, and $0.0493 \mathrm{~g}$ for en, O-PD, and DMPD, resp., $0.362 \mathrm{mmol}$ ) in a minimum amount of absolute ethanol (en, O-PD) or methanol (DMPD) containing 2 drops of piperidine an ethanolic solution of 3,4-dihydroxybenzaldehyde $(0.1 \mathrm{~g}$, $0.724 \mathrm{mmol}$ ) was added. Precipitation took place immediately giving yellow, brown, and orange-yellow products, respectively. The mixtures were heated under reflux with continuous stirring for $1 \mathrm{~h}, 1 \mathrm{~h}$, and $1.5 \mathrm{~h}$, respectively, to allow for complete precipitation. The products were filtered, washed with ethanol, methanol, and ether, and vacuum dried.

Synthesis of Binuclear $\left(\boldsymbol{C}_{1}, \boldsymbol{C}_{2}\right)$ and Tetranuclear $\left(\boldsymbol{C}_{3}\right)$ Copper Bis(bipyridyl) Schiff Base Complexes. Dinuclear copper complexes $\mathbf{C}_{1}$ and $\mathbf{C}_{2}$ were prepared as follows: to a stirred ethanolic solution of Schiff bases $(0.05 \mathrm{~g})(0.166$ and $0.143 \mathrm{mmol}$ for $\mathbf{E D H}_{4}$ and $\mathbf{P D H}_{4}$, resp.) $\mathrm{CuCl}_{2} \cdot 2 \mathrm{H}_{2} \mathrm{O}$
(0.0567 and $0.0489 \mathrm{~g}, 0.332$ and $0.286 \mathrm{mmol}$, resp.), $2,2^{\prime}$ bipyridyl (0.0519 and $0.0448 \mathrm{~g}, 0.332$ and $0.287 \mathrm{mmol}$, resp.), and triethylamine $\left(\mathrm{NEt}_{3}\right)(0.0673$ and $0.0580 \mathrm{~g}, 0.665$ and $0.574 \mathrm{mmol}$, resp.) were added in a minimum amount of ethanol. Precipitation took place immediately. Reflux was continued for $4 \mathrm{~h}$ with continuous stirring. The products were filtered off, washed with ethanol, and vacuum dried. $\mathbf{C}_{3}$ was prepared by treating an ethanolic solution of $\mathbf{M P D H}_{\mathbf{4}}$ $(0.050 \mathrm{~g}, 0.132 \mathrm{mmol})$ with a solution mixture of excess $\mathrm{CuCl}_{2} \cdot 2 \mathrm{H}_{2} \mathrm{O}(0.100 \mathrm{~g}, 0.586 \mathrm{mmol}), 2,2^{\prime}$-bipyridyl (0.0414 g, $0.265 \mathrm{mmol})$, and $\mathrm{NEt}_{3}(0.0537 \mathrm{~g}, 0.531 \mathrm{mmol})$ in ethanol. The mixture was heated under reflux for $4 \mathrm{~h}$. A brown precipitate was formed. The product was filtered off, washed several times with hot ethanol, and vacuum dried.

Synthesis of a Trinuclear Copper Bis(bipyridyl) Schiff Base Complex $\left(\boldsymbol{C}_{4}\right)$. To an ethanol solution of $\mathbf{C}_{\mathbf{1}}(0.05 \mathrm{~g}$, $0.06 \mathrm{mmol}) \mathrm{CuCl}_{2} \cdot 2 \mathrm{H}_{2} \mathrm{O}(0.0115 \mathrm{~g}, 0.06 \mathrm{mmol})$ dissolved in a minimum amount of ethanol was added with continuous stirring for $1 \mathrm{~h}$ during which the color of solution changed to dark brown. The mixture was heated under reflux for $4 \mathrm{~h}$. A 
TABLE 1: The physical properties and analytical data for Schiff bases and their metal complexes.

\begin{tabular}{|c|c|c|c|c|c|c|c|c|}
\hline \multirow{2}{*}{ Symbol } & \multirow{2}{*}{ Color } & \multirow{2}{*}{ (m.p.) ${ }^{\circ} \mathrm{C}$} & \multirow{2}{*}{ Yield \% } & \multicolumn{3}{|c|}{$\mathrm{CHN} \%$ analysis found (Calc.) } & \multirow{2}{*}{ M \% found (Calc.) } & \multirow{2}{*}{$\mathrm{Cl} \%$ found (Calc.) } \\
\hline & & & & $\mathrm{C} \%$ & $\mathrm{H} \%$ & $\mathrm{~N} \%$ & & \\
\hline $\mathrm{EDH}_{4}$ & Yellow & $210 \mathrm{dec}$. & 67.07 & $65.04(64.00)$ & $5.77(5.33)$ & $9.78(9.33)$ & - & - \\
\hline $\mathrm{PDH}_{4} \cdot 4 \mathrm{H}_{2} \mathrm{O}$ & Dark brown & 240 & 30.03 & $57.78(57.14)$ & $3.84(4.28)$ & $7.32(6.66)$ & - & - \\
\hline $\mathrm{MPDH}_{4} \cdot \mathrm{MeOH}$ & Pale yellow & 222 & 56.82 & $67.50(67.60)$ & $6.24(5.88)$ & $7.72(6.86)$ & - & - \\
\hline $\mathrm{C}_{1}$ & Brown & $>280$ & 68.92 & $53.29(53.52)$ & $4.31(4.46)$ & $10.39(10.40)$ & $16.05(15.74)$ & - \\
\hline $\mathrm{C}_{2}$ & Dark brown & $>280$ & 37.55 & $52.77(53.65)$ & $4.46(4.51)$ & $8.92(9.38)$ & $14.95(14.20)$ & - \\
\hline $\mathrm{C}_{3}$ & Brown & $>280$ & 62.24 & $46.00(45.89)$ & $3.79(3.09)$ & $8.25(7.64)$ & $23.79(23.14)$ & $12.57(12.93)$ \\
\hline $\mathrm{C}_{4}$ & Dark brown & $>280$ & 67.53 & 44.67 (44.18) & $3.78(4.09)$ & $7.80(8.59)$ & $19.92(19.50)$ & $7.47(7.26)$ \\
\hline $\mathrm{C}_{5}$ & Dark brown & $>280$ & 76.95 & $47.77(47.84)$ & $3.90(3.12)$ & $10.14(9.71)$ & $16.00(16.52)$ & $5.55(6.15)$ \\
\hline $\mathrm{C}_{6}$ & Dark brown & $>280$ & 63.57 & $46.23(46.65)$ & $3.82(3.88)$ & $9.13(8.37)$ & $14.98(14.25)$ & $5.82(5.31)$ \\
\hline $\mathrm{C}_{7}$ & Dark brown & $>280$ & 26.10 & $37.78(37.70)$ & $4.22(4.04)$ & $6.85(7.29)$ & $20.85(20.44)$ & $12.11(12.32)$ \\
\hline $\mathrm{C}_{8}$ & Dark green & $>280$ & 26.68 & $55.44(55.20)$ & $5.32(4.99)$ & $9.90(9.99)$ & $13.74(14.02)$ & $6.03(5.63)$ \\
\hline $\mathrm{C}_{9}$ & Dark brown & $>280$ & 68.06 & $59.50(58.76)$ & $4.55(3.81)$ & $11.73(11.42)$ & $17.93(17.28)$ & - \\
\hline $\mathrm{C}_{10}$ & Dark brown & $>280$ & 86.26 & $59.38(59.91)$ & $4.15(3.74)$ & $9.61(10.48)$ & $16.54(16.22)$ & - \\
\hline $\mathrm{C}_{11}$ & Brown & $>280$ & 77.00 & $58.39(58.26)$ & $4.12(4.39)$ & $8.92(9.71)$ & $15.22(14.69)$ & - \\
\hline $\mathrm{C}_{12}$ & Dark brown & $>280$ & 52.56 & $36.24(37.04)$ & $4.02(3.43)$ & $7.9(7.20)$ & $22.42(21.79)$ & 11.59 (12.17) \\
\hline $\mathrm{C}_{13}$ & Brown & $>280$ & 57.05 & $45.80(46.25)$ & $4.12(4.40)$ & $8.33(7.70)$ & $16.47(17.49)$ & $7.08(6.51)$ \\
\hline $\mathrm{C}_{14}$ & Reddish brown & $>280$ & 93.03 & $51.24(50.64)$ & $3.90(4.52)$ & $10.53(10.20)$ & $15.23(14.54)$ & $5.14(5.41)$ \\
\hline $\mathrm{C}_{15}$ & Brown & $>280$ & 65.50 & $45.18(45.81)$ & $3.96(3.66)$ & $7.93(8.55)$ & $13.91(14.55)$ & $6.05(6.07)$ \\
\hline
\end{tabular}

brown precipitate was formed. The product was filtered off, washed with ethanol, and vacuum dried.

Synthesis of Trinuclear Copper Tris(bipyridyl) Complexes of $\mathbf{E D H}_{4}\left(\boldsymbol{C}_{5}\right)$ and $\mathbf{M P D H}_{4}\left(\boldsymbol{C}_{6}\right)$. To a hot solution of $\mathrm{C}_{1}(0.05 \mathrm{~g}, 0.06 \mathrm{mmol})$ in hot ethanol $\mathrm{Cu}\left(\mathrm{ClO}_{4}\right)_{2} \cdot 6 \mathrm{H}_{2} \mathrm{O}$ $(0.0222 \mathrm{~g}, \quad 0.06 \mathrm{mmol})$ and 2,2-bipyridyl (0.0093 g, $0.06 \mathrm{mmol}$ ) in ethanol were added with continuous stirring for $1 \mathrm{~h}$ followed by heating under reflux for $4 \mathrm{~h}$ to allow for complete precipitation. The resulting product $\left(\mathbf{C}_{5}\right)$ was filtered off, washed with hot ethanol, and vacuum dried. $\mathrm{C}_{6}$ was prepared by adding a solution of $\mathrm{Cu}\left(\mathrm{ClO}_{4}\right)_{2} \cdot 6 \mathrm{H}_{2} \mathrm{O}$ (0.0678 g), 2,2' -bipyridyl (0.0285 g) (0.183 mmol each), and $\mathrm{NEt}_{3}(0.0246 \mathrm{~g}, 0.244 \mathrm{mmol})$ in ethanol to $\mathbf{M P D H}_{4}(0.0229 \mathrm{~g}$, $0.061 \mathrm{mmol}$ ) dissolved in a minimum amount of ethanol. A dark brown precipitate started to appear. The mixture was heated under reflux for 3-4 h for complete precipitation. The product was filtered, washed with hot ethanol, and vacuum dried.

Synthesis of Tetra- and Trinuclear Cobalt Bis- and Tris(bipyridyl) Complexes of $\mathbf{E D H}_{4}$ and $\mathbf{M P D H}_{4}\left(\boldsymbol{C}_{7}\right.$ and $\left.\mathbf{C}_{8}\right) \cdot \mathbf{C}_{7}$ was prepared as follows: a solution of $2,2^{\prime}$-bipyridyl $(0.0517 \mathrm{~g}, 0.332 \mathrm{mmol})$ and $\mathrm{NEt}_{3}(0.0672 \mathrm{~g}, 0.665 \mathrm{mmol})$ in a minimum amount of ethanol was added to a solution of $\mathbf{E D H}_{4}(0.0499 \mathrm{~g}, 0.1664 \mathrm{mmol})$ in warm ethanol with continuous stirring. Then a solution of $\mathrm{CoCl}_{2} \cdot 6 \mathrm{H}_{2} \mathrm{O}(0.1592 \mathrm{~g}$, $0.669 \mathrm{mmol}$ ) in ethanol was added. The color of solution was changed from blue to brown. The reaction mixture was then heated under reflux for $4 \mathrm{~h}$. A brown precipitate was formed. The product was filtered, washed with hot ethanol, and vacuum dried. The preparation and purification of $\mathbf{C}_{\mathbf{8}}$ (dark green) was carried out in the same manner, but the quantities of the reactants were $\mathrm{MPDH}_{4}(0.0625 \mathrm{~g}, 0.1664 \mathrm{mmol}), 2,2^{\prime}$ bipyridyl $(0,0778 \mathrm{~g}, 0.4992 \mathrm{mmol}), \mathrm{CoCl}_{2} \cdot 6 \mathrm{H}_{2} \mathrm{O}(0.1187 \mathrm{~g}$, $0.499 \mathrm{mmol})$, and $\mathrm{NEt}_{3}(0.0672 \mathrm{~g}, 0.665 \mathrm{mmol})$ and the color of solution after the addition of the cobalt salt was changed from yellow to green.

2.2.2. Method 2. In this method the metal complexes were prepared from condensation reaction of the $\mathrm{Cu}$ (II) complex precursor $\left(\mathbf{L C u L}{ }^{\prime}\right)\left(\mathrm{L}=2,2^{\prime}\right.$-bipyridyl, $\mathrm{L}^{\prime}=4$-formylbenzene1,2-bis(olate)) with the diamines followed by the reaction with the metal salts to form tri- and tetranuclear complexes.

Synthesis of $\mathbf{L C} \mathbf{U L}^{\prime}$. This complex was prepared by following a previously published method [11] with modification. A solution of $\mathrm{CuCl}_{2} \cdot 2 \mathrm{H}_{2} \mathrm{O}(0.1234 \mathrm{~g}, 0.724 \mathrm{mmol})$ in ethanol was added to an ethanolic mixture of 3,4-dihydroxybenzaldehyde (0.1 g, $0.724 \mathrm{mmol}), 2,2^{\prime}$-bipyridyl (0.1130 g, $\left.0.724 \mathrm{mmol}\right)$, and triethylamine $(0.1465 \mathrm{~g}, 1.448 \mathrm{mmol})$. The reaction mixture was stirred for $20 \mathrm{~min}$. at room temperature during which a brown precipitate was formed. The mixture was heated under reflux for $2 \mathrm{~h}$ and the resulting product was separated by filtration, washed with hot ethanol, and dried under vacuum. The product was characterized by elemental analysis and the FTIR spectral analysis.

Synthesis of Binuclear Copper Bis(bipyridyl) Schiff Base Complexes $C_{9}, C_{10}$, and $C_{11}$. An ethanol solution of diamine (en, O-PD, and DMPD, 0.0140, 0.0151, and 0.0191 g, resp., $0.14 \mathrm{mmol})$ was added to a solution of $\mathbf{L C u L}^{\prime}(0.1 \mathrm{~g}$, $0.28 \mathrm{mmol}$ ) in hot ethanol with stirring for $30 \mathrm{~min}$. The mixture was then heated under reflux for $3 \mathrm{~h}$ to allow for complete precipitation. The products were filtered off, washed with ethanol and ether, and vacuum dried. 
TABLE 2: Significant bands in the FTIR spectra $\left(\mathrm{cm}^{-1}\right)$ for Schiff bases and their metal complexes.

\begin{tabular}{|c|c|c|c|c|c|c|c|c|c|}
\hline Symbol & $v_{\mathrm{OH}}$ & $v_{\mathrm{C}-\mathrm{H}}$ & $v_{\mathrm{C}=\mathrm{N}}$ imine & $v_{\mathrm{C}=\mathrm{N}}$ bipy. & $v_{\mathrm{ClO} 4}$ ionic (Coord.) & $v \mathrm{H}_{2} \mathrm{O}$ lattice (Coord.) & $v_{\mathrm{M}-\mathrm{O}}$ & $\nu_{\mathrm{M}-\mathrm{N}}$ & $\nu_{\mathrm{M}-\mathrm{Cl}}$ \\
\hline $\mathrm{EDH}_{4}$ & 3263 & 2839 & $\begin{array}{l}1651 \\
1608\end{array}$ & - & - & - & - & - & - \\
\hline $\mathrm{PDH}_{4} \cdot 4 \mathrm{H}_{2} \mathrm{O}$ & 3253 & 2750 & $\begin{array}{c}1631 \\
1604\end{array}$ & - & - & $3448-3417$ & - & - & - \\
\hline $\mathrm{MPDH}_{4} \cdot \mathrm{MeOH}$ & 3251 & 2985 & 1670 & - & - & - & - & - & - \\
\hline $\mathrm{C}_{1}$ & - & $\begin{array}{l}2860 \\
2760\end{array}$ & $\begin{array}{l}1654 \\
1608\end{array}$ & 1519 & - & $(3150,767,651)$ & 420 & 370 & - \\
\hline $\mathrm{C}_{2}$ & - & 2950 & $\begin{array}{l}1640 \\
1610\end{array}$ & 1500 & - & $3400(3250,775,660)$ & 460 & 350 & - \\
\hline $\mathrm{C}_{3}$ & - & 2900 & $\begin{array}{l}1658 \\
1604\end{array}$ & 1570 & - & 3444 & 474 & 385 & $\begin{array}{l}297^{\mathrm{a}} \\
254^{\mathrm{b}}\end{array}$ \\
\hline $\mathrm{C}_{4}$ & - & $\begin{array}{l}2800 \\
2750\end{array}$ & $\begin{array}{l}1643 \\
1604\end{array}$ & 1543 & - & $(3356,771,729)$ & 470 & 385 & $340^{\mathrm{a}}$ \\
\hline $\mathrm{C}_{5}$ & - & $\begin{array}{l}2819 \\
2746\end{array}$ & $\begin{array}{l}1651 \\
1608\end{array}$ & 1570 & $1111,1083,1037$ & - & 470 & 333 & - \\
\hline $\mathrm{C}_{6}$ & - & $\begin{array}{l}2950 \\
2800\end{array}$ & $\begin{array}{l}1660 \\
1610\end{array}$ & 1570 & $(1093,1040)$ & $3580(3240,750,675)$ & 550 & 341 & - \\
\hline $\mathrm{C}_{7}$ & - & 2750 & $\begin{array}{l}1653 \\
1610\end{array}$ & 1580 & - & $3750(3300,770,650)$ & 490 & 405 & $\begin{array}{l}312^{\mathrm{a}} \\
241^{\mathrm{b}}\end{array}$ \\
\hline $\mathrm{C}_{8}$ & - & $\begin{array}{l}2980 \\
2870\end{array}$ & $\begin{array}{l}1640 \\
1610\end{array}$ & 1560 & - & $(3240,775,655)$ & 560 & 395 & $\begin{array}{l}325^{\mathrm{a}} \\
270^{\mathrm{b}}\end{array}$ \\
\hline $\mathrm{C}_{9}$ & - & $\begin{array}{l}2951 \\
2839\end{array}$ & 1655 & 1573 & - & - & 478 & 358 & - \\
\hline $\mathrm{C}_{10}$ & - & 2980 & 1630 & 1590 & - & 3550 & 490 & 400 & - \\
\hline $\mathrm{C}_{11}$ & - & $\begin{array}{l}2823 \\
2754\end{array}$ & $\begin{array}{l}1651 \\
1608\end{array}$ & 1570 & - & 3456 & 489 & 389 & - \\
\hline $\mathrm{C}_{12}$ & - & $\begin{array}{l}2950 \\
2800\end{array}$ & $\begin{array}{l}1645 \\
1600\end{array}$ & 1550 & - & $3700(3250,690,640)$ & 450 & 322 & $\begin{array}{l}304^{\mathrm{a}} \\
250^{\mathrm{b}}\end{array}$ \\
\hline $\mathrm{C}_{13}$ & - & $\begin{array}{l}2960 \\
2850\end{array}$ & $\begin{array}{l}1660 \\
1610\end{array}$ & 1550 & - & $(3300,770,640)$ & 560 & 343 & \\
\hline $\mathrm{C}_{14}$ & - & 2750 & $\begin{array}{l}1639 \\
1604\end{array}$ & 1570 & 1103,1050 & - & 459 & 393 & \\
\hline $\mathbf{C}_{15}$ & - & 2800 & 1620 & 1550 & $(1091,1050)$ & $3600(3380,771,740)$ & 510 & 400 & \\
\hline
\end{tabular}

Synthesis of Trinuclear Copper Bis(bipyridyl) Schiff Base Complexes $\boldsymbol{C}_{12}$ and $\boldsymbol{C}_{13}$. To a solution of $\mathbf{C}_{\mathbf{9}}$ and $\mathbf{C}_{11}(0.0441$ and $0.0519 \mathrm{~g}$, resp., $0.06 \mathrm{mmol}$ ) in hot ethanol $\mathrm{CuCl}_{2} \cdot 2 \mathrm{H}_{2} \mathrm{O}$ $(0.0115 \mathrm{~g}, 0.06 \mathrm{mmol})$ was added in a minimum amount of ethanol with stirring for $1 \mathrm{~h}$. The colors of solutions changed to brown and precipitation of products took place. The mixtures were heated under reflux for $4 \mathrm{~h}$ and the products were filtered off, washed with ethanol, and vacuum dried.

Synthesis of Trinuclear Copper Tris(bipyridyl) Schiff Base Complexes $\boldsymbol{C}_{\mathbf{1 4}}$ and $\boldsymbol{C}_{15}$. A solution mixture of 2,2' -bipyridyl $(0.0093 \mathrm{~g}, \quad 0.06 \mathrm{mmol})$ and $\mathrm{Cu}\left(\mathrm{ClO}_{4}\right)_{2} \cdot 6 \mathrm{H}_{2} \mathrm{O} \quad(0.0222 \mathrm{~g}$, $0.06 \mathrm{mmol})$ in ethanol was added to a solution of $\mathbf{C}_{9}$ and $\mathbf{C}_{10}(0.0441$ and $0.0536 \mathrm{~g}$, resp., $0.06 \mathrm{mmol})$ in hot ethanol with stirring for $1 \mathrm{~h}$ until the formation of precipitates was observed. The mixtures were then heated under reflux for $4 \mathrm{~h}$ and the products were filtered off, washed with hot ethanol, and vacuum dried.

\section{Results and Discussion}

3.1. Synthesis. The synthesis routes for the metal complexes by the two methods are illustrated in Scheme 1. Method 1 involves the condensation reaction of the diamines with two molecules of 3,4-dihydroxybenzaldehyde $\left(\mathrm{L}^{\prime} \mathrm{H}_{2}\right)$ to form the diSchiff bases as a first step for the formation of metal complexes. In the second method the condensation reaction occurs between the diamine molecule and two molecules of the mixed ligand copper complex precursor $\mathbf{L} \mathbf{C u L} \mathbf{L}^{\prime}$. Although the last method is simpler than the first method to avoid side reactions, the copper complex precursor is slightly soluble in cold ethanol and therefore reaction with this complex required heating in large amount of solvent. 


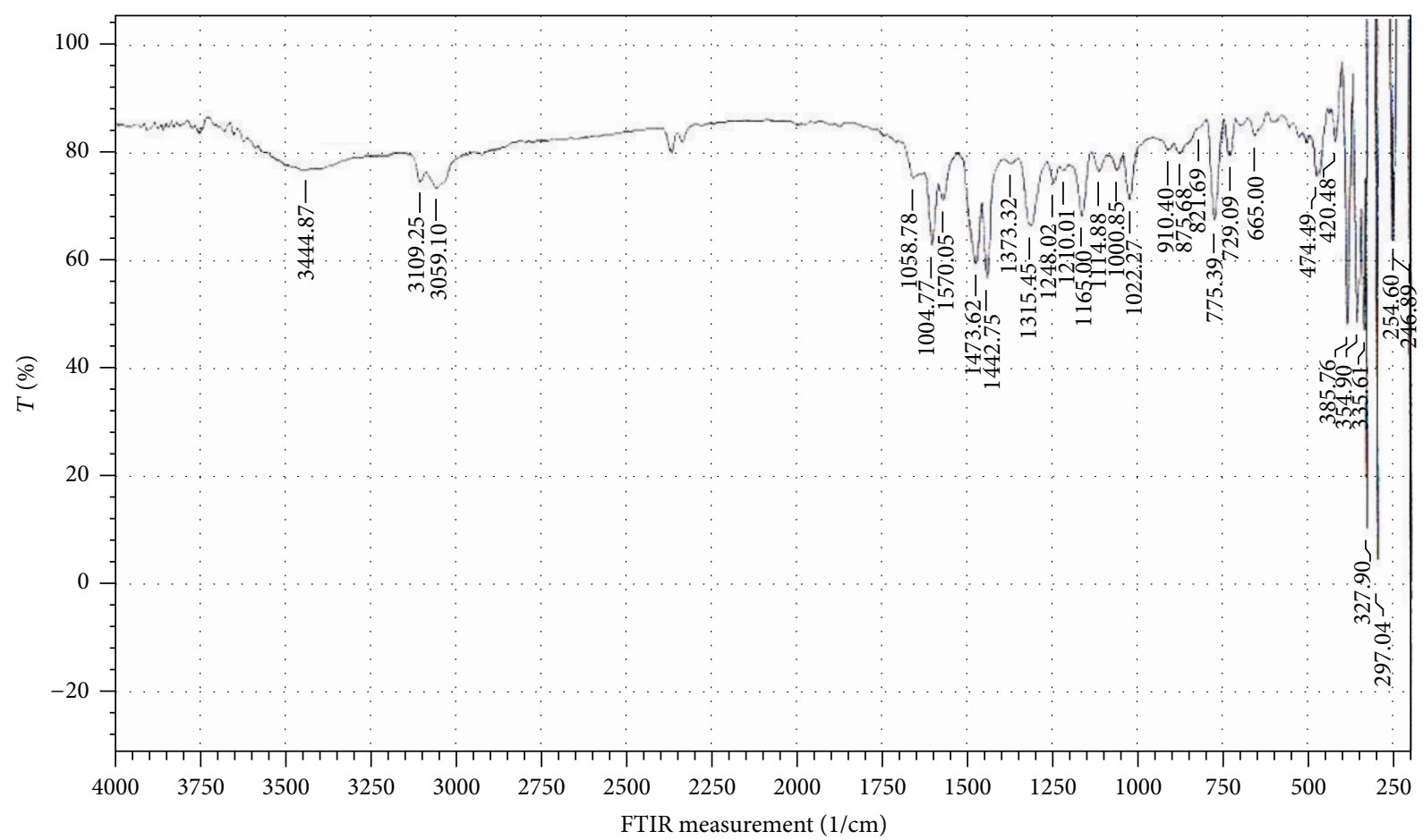

(a)

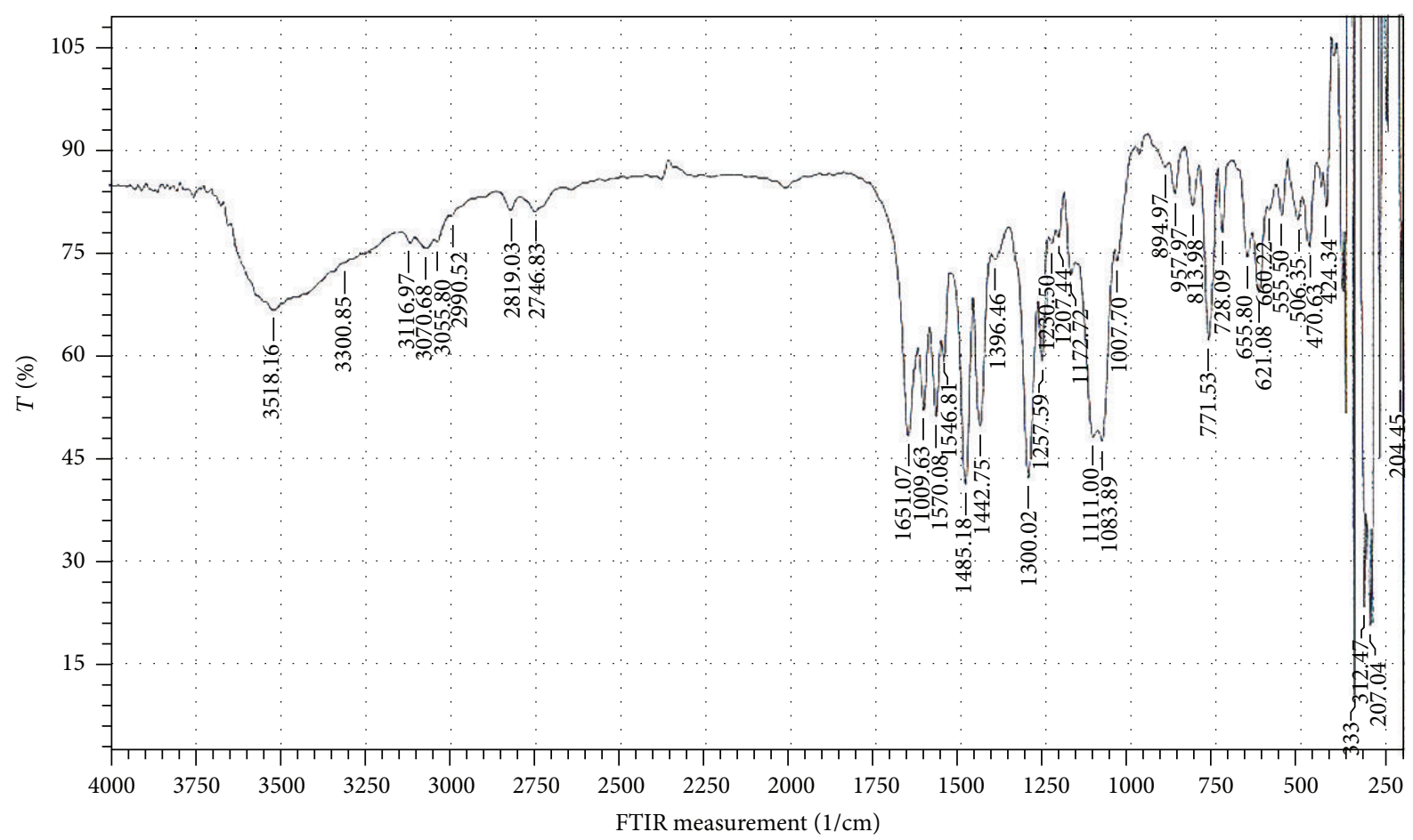

(b)

FIgURE 5: FTIR spectra of (a) $\mathbf{C}_{3}$ and (b) $\mathbf{C}_{5}$.

3.2. Physical Properties. The physical properties and results obtained from elemental analyses of the prepared compounds are described in Table 1 . The analytical data are quite agreeable with calculated values with few exceptions which were attributed to incomplete combustion of the compounds. The molecular formula of the prepared compounds has been suggested according to the aforementioned data together with those obtained from spectral and thermal analyses as well 


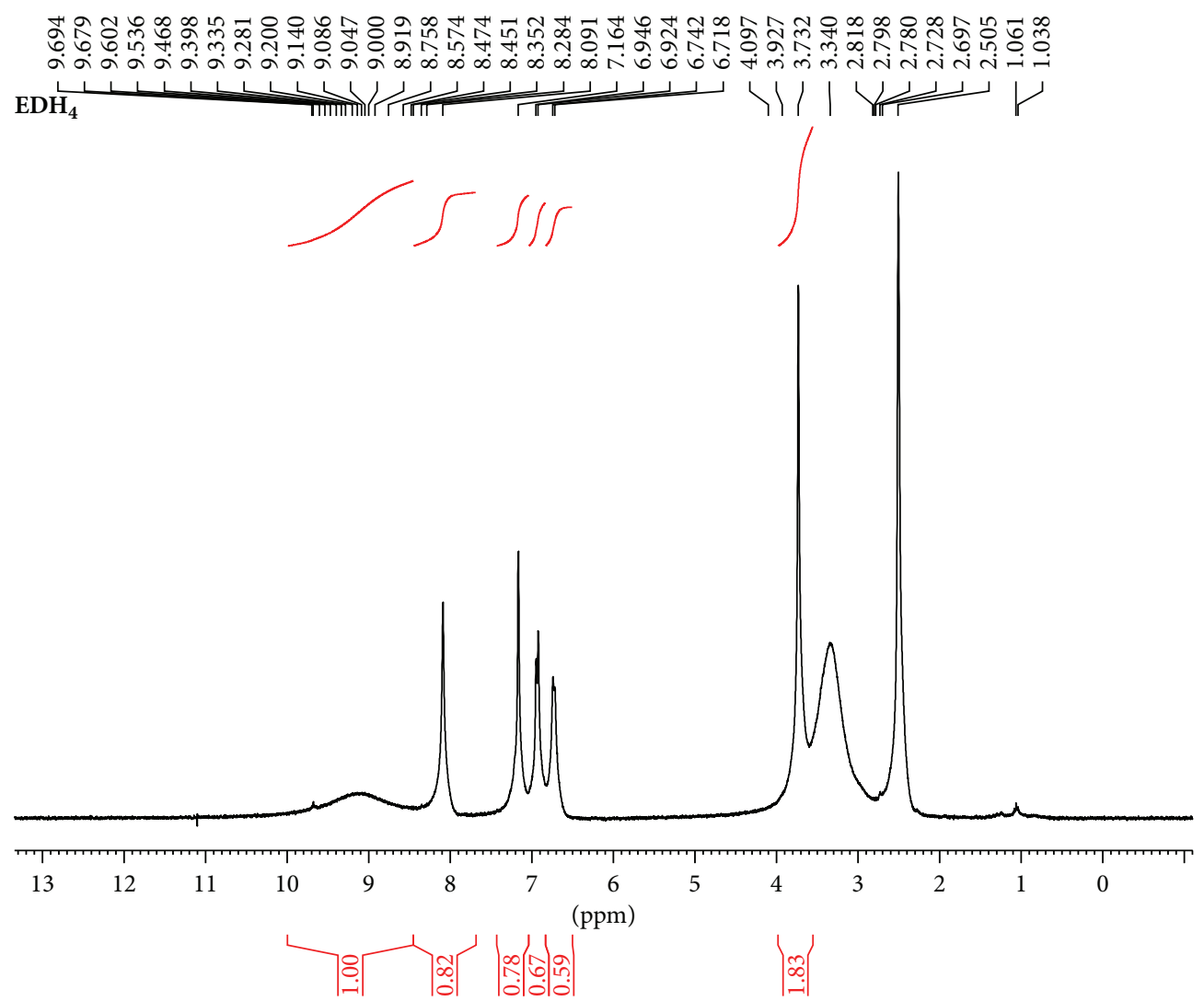

(a)

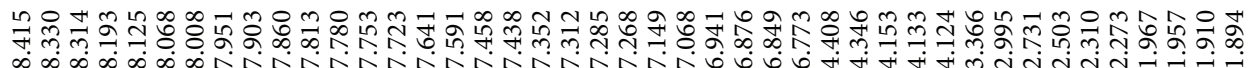

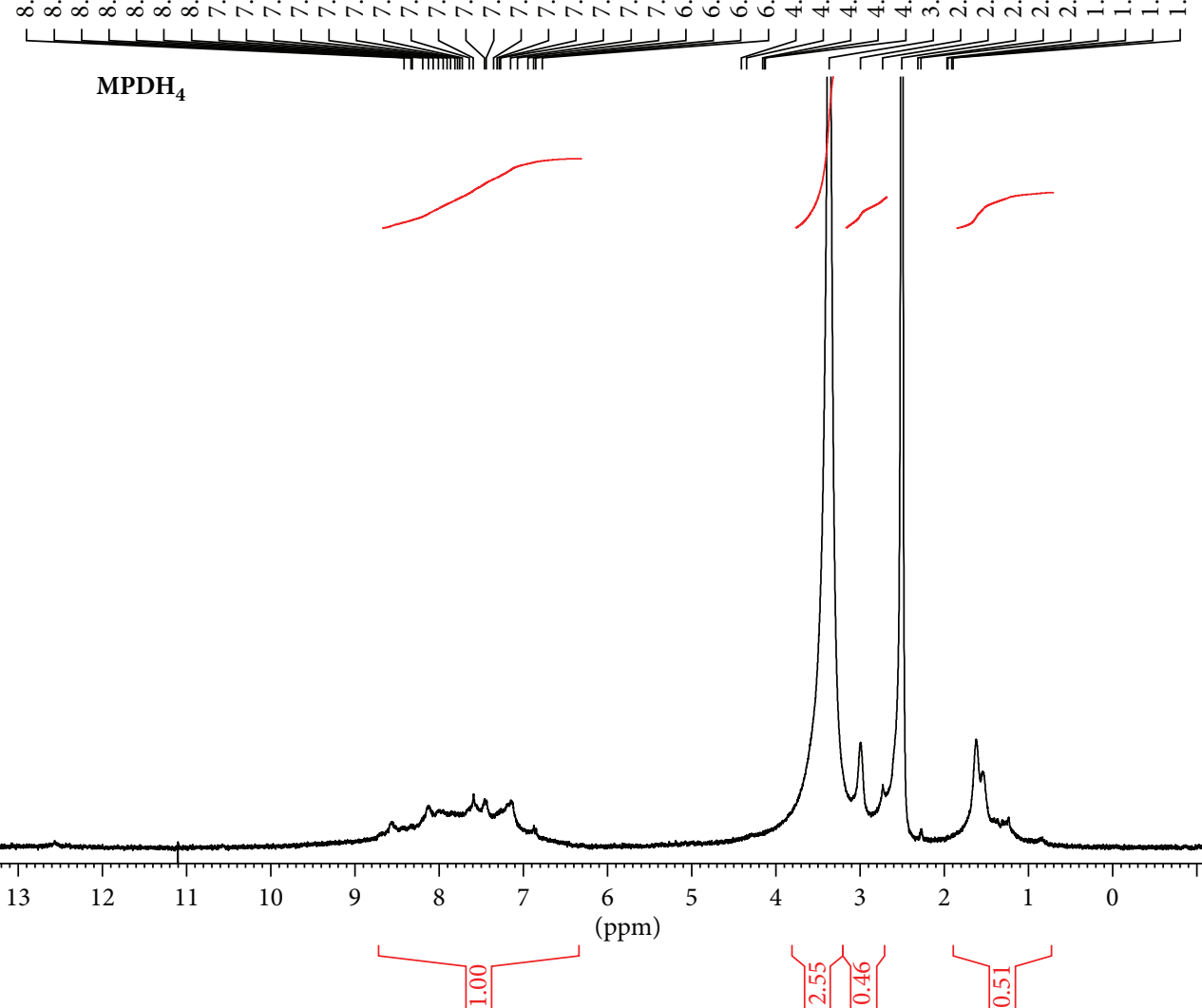

(b)

FIGURE 6: ${ }^{1} \mathrm{H}$ NMR spectra of diSchiff base ligands $\mathbf{E D H}_{4}$ and $\mathbf{M P D H}_{4}$. 
TABle 3: ${ }^{1} \mathrm{H}$ NMR data of the three Schiff base ligands and the $\mathrm{Cu}(\mathrm{II})$ complex $\mathbf{C}_{11}$ in DMSO.

\begin{tabular}{|c|c|c|c|}
\hline \multicolumn{2}{|c|}{$\mathrm{EDH}_{4}$} & \multicolumn{2}{|r|}{$\mathrm{PDH}_{4}$} \\
\hline Chemical shift $\delta(\mathrm{ppm})$ & Assignments & Chemical shifts $\delta$ (ppm) & Assignments \\
\hline$(8.8-9.9,4 \mathrm{H}, \mathrm{b})$ & Protons of $\mathrm{OH}$ & $(9.60-9.75,4 \mathrm{H}, \mathrm{b})$ & Protons of $\mathrm{OH}$ \\
\hline$(8.1,2 \mathrm{H}, \mathrm{s})$ & Protons of azomethine & $(8.7-7.9,2 \mathrm{H}, \mathrm{b})$ & Protons of azomethine \\
\hline$(6.7-7.4,6 \mathrm{H}, \mathrm{m})$ & Aromatic protons & $(6.5-7.9,10 \mathrm{H}, \mathrm{b})$ & Aromatic protons \\
\hline$(3.9,4 \mathrm{H}, \mathrm{s})$ & Protons of $\mathrm{NCH}_{2}$ & $(3-3.5,8 \mathrm{H}, \mathrm{b})$ & Protons of $\mathrm{H}_{2} \mathrm{O}$ \\
\hline$(3-3.5,2 \mathrm{H}, \mathrm{b})$ & Protons of $\mathrm{H}_{2} \mathrm{O}$ (in DMSO) & $(2.5,6 \mathrm{H}, \mathrm{s})$ & Protons of DMSO \\
\hline$(2.5,6 \mathrm{H}, \mathrm{s})$ & Protons of DMSO & & \\
\hline \multicolumn{2}{|c|}{$\mathrm{MPDH}_{4}$} & \multicolumn{2}{|r|}{$\mathrm{C}_{11}$ complex } \\
\hline Chemical shifts $\delta$ (ppm) & Assignments & Chemical shifts $\delta$ (ppm) & Assignments \\
\hline$(8.5-8.68,4 \mathrm{H}, \mathrm{b})$ & Protons of $\mathrm{OH}$ & $(10.1-10.98,2 \mathrm{H}, \mathrm{b})$ & Protons of azomethine \\
\hline$(8.0-8.28,2 \mathrm{H}, \mathrm{b})$ & Protons of azomethine & $(6.7-7.5,24 \mathrm{H}, \mathrm{b})$ & Aromatic protons of benzene rings and bipyridyl \\
\hline$(6.9-7.6,10, \mathrm{~m})$ & Aromatic protons & $(3.2,6 \mathrm{H}, \mathrm{m})$ & Protons of $\mathrm{H}_{2} \mathrm{O}$ \\
\hline$(3.0-3.6,2 \mathrm{H}, \mathrm{m})$ & Protons of $\mathrm{H}_{2} \mathrm{O}$ & $(2.4-2.8,6 \mathrm{H}, \mathrm{m})$ & Protons of DMSO \\
\hline$(2.5,6 \mathrm{H}, \mathrm{s})$ & Protons of DMSO & $(0.97-1.85,6 \mathrm{H}, \mathrm{b})$ & Protons of $\mathrm{CH}_{3}$ \\
\hline$(1.5-1.7,6 \mathrm{H}, \mathrm{m})$ & Protons of $\mathrm{CH}_{3}$ & - & - \\
\hline
\end{tabular}

TABLE 4: Chemical shifts (ppm) for ${ }^{13} \mathrm{C}$ NMR of Schiff bases $\mathbf{E D H}_{\mathbf{4}}$ and $\mathrm{MPDH}_{4}$ in DMSO.

\begin{tabular}{lcc}
\hline Compound & Chemical shifts $\delta(\mathrm{ppm})$ & Assignments \\
\hline \multirow{2}{*}{$\mathbf{E D H}_{4}$} & 60.99 & Carbon of $\mathrm{CH}_{2}$ \\
& $113.6-161.2$ & Aromatic carbons \\
& 167.2 & Carbon of HC=N \\
\hline \multirow{2}{*}{$\mathbf{M P D H}_{4}$} & $19.8,20.1$ & Carbon of methyl group \\
& $110.8-146.8$ & Aromatic carbons \\
& $150.6,152.7$ & Carbon of HC=N \\
\hline
\end{tabular}

as conductivity and magnetic susceptibility measurements of metal complexes. All complexes were noncrystalline which made it difficult to obtain their single crystal structures.

3.3. Infrared Spectra. The important vibrational modes of IR spectra for the free Schiff bases and their metal complexes are described in Table 2. The spectra of the free ligands displayed strong to moderate absorption band in the wavenumber region $3251-3263 \mathrm{~cm}^{-1}$ which were assigned to intramolecular hydrogen bonding of the two adjacent $\mathrm{OH}$ groups [12]. These bands were absent in the spectra of all metal complexes which indicates that the phenolic oxygen atoms were bonded to the metal ions $[3-5,11]$. The spectrum of the mixed ligand copper (II) complex precursor CuLL' displayed strong absorption bands at 1660 and $1540 \mathrm{~cm}^{-1}$ assigned to the stretching vibrations of the $\mathrm{C}=\mathrm{O}$ and $\mathrm{C}=\mathrm{N}$ groups of $\mathrm{L}^{\prime}$ and $\mathrm{L}$ moieties, respectively $[11,13]$. The low intensity bands observed at lower wavenumber region at 440 and $345 \mathrm{~cm}^{-1}$ were assignable to stretching vibrations of $\mathrm{Cu}-$ $\mathrm{O}$ and $\mathrm{Cu}-\mathrm{N}$ bonds, respectively $[3,5]$.

The strong bands observed at $1631-1670 \mathrm{~cm}^{-1}$ and 1604 , $1608 \mathrm{~cm}^{-1}$ in the spectra of the free Schiff bases were assigned to the asymmetric symmetric stretching vibration of the azomethine group $(\nu \mathrm{C}=\mathrm{N})[2-5]$. These bands were shifted to lower frequency in all complexes (except $\mathrm{C}_{1}, \mathrm{C}_{2}, \mathrm{C}_{9}$, $\mathbf{C}_{10}$, and $\mathbf{C}_{11}$ ) indicating the coordination of the Schiff bases with the metal ions through the azomethine nitrogens [5]. All complexes exhibited strong bands at wavenumber range $1500-1590 \mathrm{~cm}^{-1}$ attributed to $v_{\mathrm{C}=\mathrm{N}}$ of coordinated bipyridyl ligand [14]. The spectra of the complexes $\mathbf{C}_{5}, \mathbf{C}_{\mathbf{6}}, \mathbf{C}_{\mathbf{1 4}}$, and $\mathbf{C}_{15}$ exhibited strong bands assigned to the stretching vibrational modes of $\mathrm{ClO}_{4}$ anion $\left(\nu_{\mathrm{ClO}_{4}}\right)$ which behaved as monodentate ligand in $\mathbf{C}_{6}$ and $\mathbf{C}_{15}$ complexes [15] and as a free ion in $\mathbf{C}_{5}$ and $\mathbf{C}_{14}$ complexes [15]. The bands appeared at 3400$3750 \mathrm{~cm}^{-1}$ in the spectra of $\mathbf{P D H}_{4}, \mathbf{C}_{2}, \mathbf{C}_{3}, \mathbf{C}_{6}, \mathbf{C}_{7}, \mathbf{C}_{10}$, $\mathrm{C}_{11}, \mathrm{C}_{12}$, and $\mathrm{C}_{15}$ were attributed to vibrational modes of lattice $\mathrm{H}_{2} \mathrm{O}$ [15], while the bands which appeared at 3100$3380 \mathrm{~cm}^{-1}$ and $621-775 \mathrm{~cm}^{-1}$ in the spectra of $\mathrm{C}_{1}, \mathrm{C}_{2}, \mathrm{C}_{4}$, $\mathrm{C}_{6}, \mathrm{C}_{7}, \mathrm{C}_{8}, \mathrm{C}_{12}, \mathrm{C}_{13}$, and $\mathrm{C}_{15}$ were due to coordinated $\mathrm{H}_{2} \mathrm{O}$ [15]. The spectrum of $\mathbf{M P D H}_{4}$ exhibited a strong band in the range $3552-3421 \mathrm{~cm}^{-1}$ and another band at $1195-1161 \mathrm{~cm}^{-1}$ attributed to $\mathrm{OH}$ and $\mathrm{C}-\mathrm{O}$ stretching vibrations of methanol embedded in the crystal lattice of the ligand $[13,15]$. Further bands which appeared at lower frequencies in the spectra of metal complexes were assigned to $\mathrm{M}-\mathrm{O}, \mathrm{M}-\mathrm{N}$ and $\mathrm{M}-\mathrm{Cl}$ stretching vibrations (Table 2). Figure 5 shows representative FTIR spectra of $\mathbf{C}_{3}$ and $\mathbf{C}_{5}$ prepared by method 1 from $\mathrm{MPDH}_{4}$ and $\mathrm{EDH}_{4}$, respectively.

3.4. ${ }^{1} \mathrm{H} N M R$ and ${ }^{13} \mathrm{C}$ NMR Spectra. The ${ }^{1} \mathrm{H}$ NMR spectra of diSchiff bases and the binuclear bis(bipyridyl) copper complex of $\mathbf{M P D H}_{4}\left(\mathbf{C}_{11}\right)$ were recorded in DMSO and the chemical shifts and peak assignments are given in Table 3. The spectra of the Schiff base ligands showed a broad peak in the range $\delta=8.5-9.9 \mathrm{ppm}$ attributed to phenolic hydroxyl protons $[3,4,16]$ as is demonstrated by the spectra of $\mathbf{E D H}_{4}$ and $\mathrm{MPDH}_{4}$ shown in Figure 6.

The absence of this peak in the spectrum of complex $\mathbf{C}_{11}$ (Table 3) confirms the involvement of deprotonated hydroxyls in chelation to the metal ion $[16,17]$. The peaks displayed 
TABLE 5: Electronic spectra, magnetic moments, and molar conductivity data of Schiff bases and their metal complexes.

\begin{tabular}{|c|c|c|c|c|}
\hline Symbol & Band positions $\left(\mathrm{cm}^{-1}\right)$ & Assignment & $\mu_{\mathrm{eff}}(\mathrm{B} . \mathrm{M})$ & Molar conductivity $\mathrm{S} \cdot \mathrm{mol}^{-1} \cdot \mathrm{cm}^{2}$ in DMF \\
\hline $\mathrm{EDH}_{4}$ & 33222,24691 & $\pi \rightarrow \pi^{*}$ & - & 0.0018 \\
\hline \multirow{2}{*}{$\mathrm{PDH}_{4}$} & 33222,27777 & $\pi \rightarrow \pi^{*}$ & \multirow{2}{*}{-} & \multirow{2}{*}{0.011} \\
\hline & 20833 & $n \rightarrow \pi^{*}$ & & \\
\hline \multirow{2}{*}{$\mathrm{MPDH}_{4}$} & 33333 & $\pi \rightarrow \pi^{*}$ & \multirow{2}{*}{-} & \multirow{2}{*}{0.0007} \\
\hline & 27777 & $n \rightarrow \pi^{*}$ & & \\
\hline \multirow{4}{*}{$\mathrm{C}_{1}$} & 32362,29154 & Intraligand $\pi \rightarrow \pi^{*}$ & \multirow{4}{*}{0.386 oh } & \multirow{4}{*}{0.022} \\
\hline & 23255 & C.T & & \\
\hline & 15431 & ${ }^{2} \mathrm{~B}_{1} \mathrm{~g} \rightarrow{ }^{2} \mathrm{~B}_{2} \mathrm{~g}$ & & \\
\hline & 13513 & ${ }^{2} \mathrm{~B}_{1} \mathrm{~g} \rightarrow{ }^{2} \mathrm{~A}_{1} \mathrm{~g}$ & & \\
\hline \multirow{3}{*}{$\mathrm{C}_{2}$} & 33444 & Intraligand $\pi \rightarrow \pi^{*}$ & \multirow{3}{*}{$0.514 \mathrm{oh}$} & \multirow{3}{*}{0.251} \\
\hline & 26315 & C.T & & \\
\hline & 18868 & ${ }^{2} \mathrm{~B}_{1} \mathrm{~g} \rightarrow{ }^{2} \mathrm{~B}_{2} \mathrm{~g}$ & & \\
\hline \multirow{4}{*}{$\mathrm{C}_{3}$} & 33333 & Intraligand $\pi \rightarrow \pi^{*}$ & \multirow{4}{*}{1.260 Sq. } & \multirow{4}{*}{0.093} \\
\hline & 25641 & C.T & & \\
\hline & 15625 & ${ }^{2} \mathrm{~B}_{1} \mathrm{~g} \rightarrow{ }^{2} \mathrm{~B}_{2} \mathrm{~g}$ & & \\
\hline & 12658 & ${ }^{2} \mathrm{~B}_{1} \mathrm{~g} \rightarrow{ }^{2} \mathrm{~A}_{1} \mathrm{~g}$ & & \\
\hline \multirow{4}{*}{$\mathrm{C}_{4}$} & 37735,34843 & Intraligand $\pi \rightarrow \pi^{*}$ & \multirow{4}{*}{$1.023 \mathrm{oh}$} & \multirow{4}{*}{0.046} \\
\hline & 27247 & C.T & & \\
\hline & 23148 & ${ }^{2} \mathrm{~B}_{1} \mathrm{~g} \rightarrow{ }^{2} \mathrm{Eg}$ & & \\
\hline & 10989 & ${ }^{2} \mathrm{~B}_{1} \mathrm{~g} \rightarrow{ }^{2} \mathrm{~A}_{1} \mathrm{~g}$ & & \\
\hline \multirow{3}{*}{$\mathrm{C}_{5}$} & 34013,27247 & Intraligand $\pi \rightarrow \pi^{*}$ & \multirow{3}{*}{$1.061 \mathrm{Sq}}$. & \multirow{3}{*}{149} \\
\hline & 23313 & C.T & & \\
\hline & 16025 & ${ }^{2} \mathrm{~B}_{1} \mathrm{~g} \rightarrow{ }^{2} \mathrm{~B}_{2} \mathrm{~g}$ & & \\
\hline & 34129,28571 & Intraligand $\pi \rightarrow \pi^{*}$ & & \\
\hline $\mathrm{C}_{6}$ & 25974 & C.T & $0810 \mathrm{oh}$ & 0.114 \\
\hline$U_{6}$ & 22883 & ${ }^{2} \mathrm{~B}_{1} \mathrm{~g} \rightarrow{ }^{2} \mathrm{Eg}$ & 0.010 on & 0.114 \\
\hline & 10460 & ${ }^{2} \mathrm{~B}_{1} \mathrm{~g} \rightarrow{ }^{2} \mathrm{~A}_{1} \mathrm{~g}$ & & \\
\hline & 36363,33333 & Intraligand $\pi \rightarrow \pi^{*}$ & $2.440 \mathrm{oh}$ & 0.043 \\
\hline & 31250 & & & \\
\hline $\mathrm{C}_{7}$ & 26178 & C.T & & \\
\hline 7 & 15731 & ${ }^{4} \mathrm{~T}_{1} \mathrm{~g} \rightarrow{ }^{4} \mathrm{~T}_{1} \mathrm{~g}(\mathrm{P})$ & & \\
\hline & 10504 & ${ }^{4} \mathrm{~T}_{1} \mathrm{~g} \rightarrow{ }^{4} \mathrm{~A}_{2} \mathrm{~g}$ & & \\
\hline & $7083 \mathrm{cal}$. & ${ }^{4} \mathrm{~T}_{1} \mathrm{~g} \rightarrow{ }^{4} \mathrm{~T}_{2} \mathrm{~g}$ & & \\
\hline & 34843,33003 & Intraligand $\pi \rightarrow \pi^{*}$ & $0.200 \mathrm{oh}$ & 0.273 \\
\hline & 28248 & C.T & & \\
\hline $\mathrm{C}_{8}$ & 15983. & ${ }^{4} \mathrm{~T}_{1} \mathrm{~g} \rightarrow{ }^{4} \mathrm{~T}_{1} \mathrm{~g}(\mathrm{P})$ & & \\
\hline & 9900 & ${ }^{4} \mathrm{~T}_{1} \mathrm{~g} \rightarrow{ }^{4} \mathrm{~A}_{2} \mathrm{~g}$ & & \\
\hline & $6456 \mathrm{cal}$. & ${ }^{4} \mathrm{~T}_{1} \mathrm{~g} \rightarrow{ }^{4} \mathrm{~T}_{2} \mathrm{~g}$ & & \\
\hline & 36363,27247 & Intraligand $\pi \rightarrow \pi^{*}$ & $1.092 \mathrm{Sq}$. & 0.0002 \\
\hline & 23310 & C.T & & \\
\hline $\mathrm{C}_{9}$ & 19920 & ${ }^{2} \mathrm{~B}_{1} \mathrm{~g} \rightarrow{ }^{2} \mathrm{Eg}$ & & \\
\hline & 15313 & ${ }^{2} \mathrm{~B}_{1} \mathrm{~g} \rightarrow{ }^{2} \mathrm{~B}_{2} \mathrm{~g}$ & & \\
\hline & 10298 & ${ }^{2} \mathrm{~B}_{1} \mathrm{~g} \rightarrow{ }^{2} \mathrm{~A}_{1} \mathrm{~g}$ & & \\
\hline & 29585 & Intraligand $\pi \rightarrow \pi^{*}$ & $2.017 \mathrm{Sq}$. & 0.005 \\
\hline $\mathrm{C}_{1}$ & 26041 & C.T & & \\
\hline$U_{11}$ & 21739 & ${ }^{2} \mathrm{~B}_{1} \mathrm{~g} \rightarrow{ }^{2} \mathrm{Eg}$ & & \\
\hline & 15873 & ${ }^{2} \mathrm{~B}_{1} \mathrm{~g} \rightarrow{ }^{2} \mathrm{~B}_{2} \mathrm{~g}$ & & \\
\hline & 36496,32894 & Intraligand $\pi \rightarrow \pi^{*}$ & $1.023 \mathrm{oh}$ & 0.013 \\
\hline $\mathrm{C}_{12}$ & 27624 & C.T & & \\
\hline$U_{12}$ & 22935 & ${ }^{2} \mathrm{~B}_{1} \mathrm{~g} \rightarrow{ }^{2} \mathrm{Eg}$ & & \\
\hline & 10482 & ${ }^{2} \mathrm{~B}_{1} \mathrm{~g} \rightarrow{ }^{2} \mathrm{~A}_{1} \mathrm{~g}$ & & \\
\hline
\end{tabular}


TABLE 5: Continued.

\begin{tabular}{|c|c|c|c|c|}
\hline Symbol & Band positions $\left(\mathrm{cm}^{-1}\right)$ & Assignment & $\mu_{\mathrm{eff}}(\mathrm{B} . \mathrm{M})$ & Molar conductivity $S \cdot \mathrm{mol}^{-1} \cdot \mathrm{cm}^{2}$ in DMF \\
\hline \multirow{3}{*}{$\mathrm{C}_{13}$} & 33333,29239 & Intraligand $\pi \rightarrow \pi^{*}$ & 0.440 & 163 \\
\hline & 27027 & C.T & & \\
\hline & 22472 & ${ }^{2} \mathrm{~B}_{1} \mathrm{~g} \rightarrow{ }^{2} \mathrm{Eg}$ & & \\
\hline \multirow{3}{*}{$\mathrm{C}_{14}$} & 34013,29154 & Intraligand $\pi \rightarrow \pi^{*}$ & $1.89 \mathrm{Sq}$. & 158 \\
\hline & 27027 & C.T & & \\
\hline & 18833. & ${ }^{2} \mathrm{~B}_{1} \mathrm{~g} \rightarrow{ }^{2} \mathrm{~B}_{2} \mathrm{~g}$ & & \\
\hline \multirow{3}{*}{$\mathrm{C}_{15}$} & 29325 & Intraligand $\pi \rightarrow \pi^{*}$ & $1.783 \mathrm{oh}$ & 0.023 \\
\hline & 27397 & C.T & & \\
\hline & 22727 & ${ }^{2} \mathrm{~B}_{1} \mathrm{~g} \rightarrow{ }^{2} \mathrm{Eg}$ & & \\
\hline
\end{tabular}

by ${ }^{1} \mathrm{H}$ NMR spectra of Schiff bases in the range $\delta=7.9-$ $8.7 \mathrm{ppm}$ were attributed to chemical shifts of the azomethine protons $(\mathrm{HC}=\mathrm{N})[3,4,16,17]$. The spectrum of $\mathbf{C}_{11}$ exhibited the absence of the signals related to $\mathrm{OH}$ protons and the appearance of the azomethine proton signals downfield which confirms the formation of the metal complex $[16,17]$.

Signals of aromatic and aliphatic protons were observed in the chemical shift ranges 6.5-7.9 and 1.5-3.9 ppm, respectively [13]. Chemical shifts for ${ }^{13} \mathrm{C}$ NMR of $\mathbf{E D H}_{4}$ and $\mathbf{M P D H}_{4}$ in DMSO are described in Table 4. The signals assigned to the chemical shifts of methylene and methyl groups for the two ligands, respectively, were observed at $60.99\left(\mathrm{CH}_{2}\right)$ and at 19.8 and $20.1\left(\mathrm{CH}_{3}\right)$ ppm [18], while the signals of aromatic carbons were located at 113.6-161.2 and $110.8-146.8 \mathrm{ppm}$, respectively $[18,19]$. The signals observed at 167.2 and $150.6-152.7 \mathrm{ppm}$, respectively, were attributed to the chemical shifts of azomethine carbons which confirms the formation of the Schiff bases [20-22].

3.5. Electronic Spectra Conductivity and Magnetic Susceptibility Measurements. The results of electronic spectra of the ligands and their metal complexes in DMF are described in Table 5. The three ligands exhibited high intensity bands which appeared at wavenumber region $33333-24390 \mathrm{~cm}^{-1}$ and low intensity bands at $27777-20833 \mathrm{~cm}^{-1}$ which were assigned to $\pi \rightarrow \pi^{*}$ and $n \rightarrow \pi^{*}$ transitions, respectively [13]. The spectra of metal complexes exhibited hypsochromic shifts of the ligand $\pi \rightarrow \pi^{*}$ band which refers to complex formation with the metal ions [18]. The spectra of complexes exhibited additional medium intensity bands in the near Uv to visible region at $28248-23255 \mathrm{~cm}^{-1}$ which were attributed to charge transfer transitions [23]. The copper complexes $\left(\mathbf{C}_{3}\right.$, $\mathbf{C}_{5}, \mathbf{C}_{9}, \mathbf{C}_{10}, \mathbf{C}_{11}$, and $\mathbf{C}_{14}$ ) displayed bands in the regions $12970-10298 \mathrm{~cm}^{-1}, 18833-15313 \mathrm{~cm}^{-1}$, and $21739-19920 \mathrm{~cm}^{-1}$ assigned to ${ }^{2} \mathrm{~B}_{1 \mathrm{~g}} \rightarrow{ }^{2} \mathrm{~A}_{1 \mathrm{~g}},{ }^{2} \mathrm{~B}_{1 \mathrm{~g}} \rightarrow{ }^{2} \mathrm{~B}_{2 \mathrm{~g}}$, and ${ }^{2} \mathrm{~B}_{1 \mathrm{~g}} \rightarrow{ }^{2} \mathrm{E}_{\mathrm{g}}$ transitions, respectively, of square planar $\mathrm{Cu}$ (II) complexes [2327] while the spectra of the copper complexes $\left(\mathbf{C}_{1}, \mathbf{C}_{2}, \mathbf{C}_{4}\right.$, $\mathbf{C}_{6}, \mathbf{C}_{12}, \mathbf{C}_{13}$, and $\mathbf{C}_{15}$ ) displayed bands in the regions 1351310460, 18868-15431, and 23148-22472 which were attributed to the transitions of tetragonally distorted octahedral $\mathrm{Cu}$ (II) complexes [23-25]. The two cobalt complexes $\left(\mathbf{C}_{7}\right.$ and $\left.\mathbf{C}_{8}\right)$ exhibited two bands observed at 15731 and $15983 \mathrm{~cm}^{-1}$, respectively, which were assigned to ${ }^{4} \mathrm{~T}_{1 \mathrm{~g}} \rightarrow{ }^{4} \mathrm{~T}_{1 \mathrm{~g}}(\mathrm{P})\left(\nu_{3}\right)$ and at 10504 and $9900 \mathrm{~cm}^{-1}$, respectively, corresponding to the transition ${ }^{4} \mathrm{~T}_{1 \mathrm{~g}} \rightarrow{ }^{4} \mathrm{~A}_{2 \mathrm{~g}}\left(\nu_{2}\right)$ of octahedral Co(II) complexes [23]. The energies of $v_{1}\left({ }^{4} \mathrm{~T}_{1 \mathrm{~g}} \rightarrow{ }^{4} \mathrm{~T}_{2 \mathrm{~g}}\right)$ as well as the values of the spectral parameters $\mathrm{Dq} / \mathrm{B}^{\prime}, \mathrm{B}^{\prime}, 10 \mathrm{Dq}$, and nephelauxetic ratio $\beta$ for the $\mathrm{Co}(\mathrm{II})$ complexes $\mathrm{C}_{7}\left(7083 \mathrm{~cm}^{-1}, 0.9\right.$, $787 \mathrm{~cm}^{-1}, 7080 \mathrm{~cm}^{-1}$, and 0.811 , resp. $)$, and $\mathrm{C}_{8}\left(6456 \mathrm{~cm}^{-1}\right.$, $0.7,807 \mathrm{~cm}^{-1}, 5740 \mathrm{~cm}^{-1}$, and 0.831 , resp.), were calculated by applying the band ratio $\nu_{3} / \nu_{2}$ on Tanabe-Sugano diagram of $\mathrm{d}^{7}$ complexes. The values of $\beta$ indicate a covalent bonding character of both complexes [23]. Conductivity measurements in DMF showed nonelectrolytic nature for all compounds (Table 3) except $\mathbf{C}_{5}, \mathbf{C}_{13}$, and $\mathbf{C}_{14}$ which were electrolytes with ionic ratio $(1: 2)$ [28]. Magnetic susceptibility measurements at room temperature showed that the magnetic moment $\left(\mu_{\text {eff }}\right)$ of the $\mathrm{Cu}(\mathrm{II})$ complex precursor CuLL' (1.69 B.M) agrees with square planar geometry of the complex $[11,23]$. The values of $\mu_{\text {eff }}$ of the other complexes were less than those expected for copper and cobalt ions which imply that the di- and trinuclear copper (II) and cobalt (II) complexes possess antiferromagnetic properties by a strong intramolecular antiferromagnetic spin exchange interaction [5]. According to the aforementioned results in addition to elemental analysis and FTIR and NMR spectra the stereochemical structures of the studied complexes were suggested as is illustrated in Scheme 2.

3.6. Thermal Analysis. Thermogravimetric (TG) and differential thermogravimetric (DTG) analyses for the two complexes $\mathbf{C}_{\mathbf{8}}$ and $\mathbf{C}_{12}$ are shown in Figure 7 . The decomposition temperature and the weight losses are described in Table 6. The loss of solvent molecules embedded in the crystal lattice of the complexes as well as uncoordinated ligand groups took place at the first stage at temperature range $78-180^{\circ} \mathrm{C}$ with peak temperatures at 100 and $98^{\circ} \mathrm{C}$, respectively, as is indicated by the DTG curves of the two complexes (Figure 7). The successive loss of coordinated water molecules occurred in the second and third stages at peak temperatures 195, 300 and $210,325^{\circ} \mathrm{C}$, respectively. The loss of bipyridyl and chloride ligands took place at temperature range $400-900^{\circ} \mathrm{C}$. The DTG curve of $\mathbf{C}_{8}$ showed three peaks at 412,620 , and $822^{\circ} \mathrm{C}$ for this stage. The high percentage of the remaining 


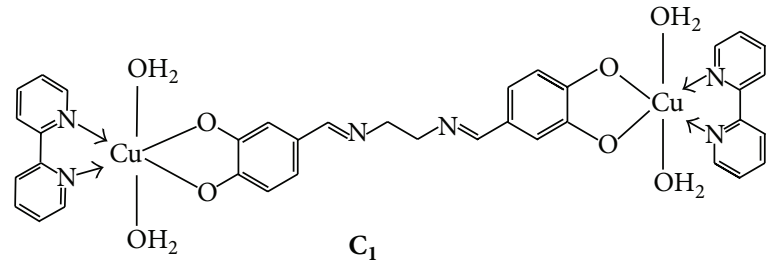

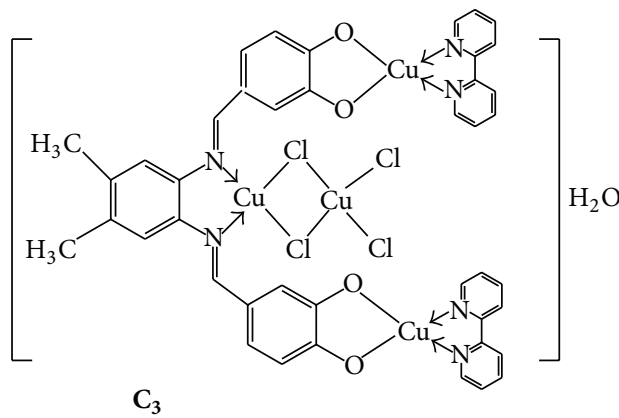

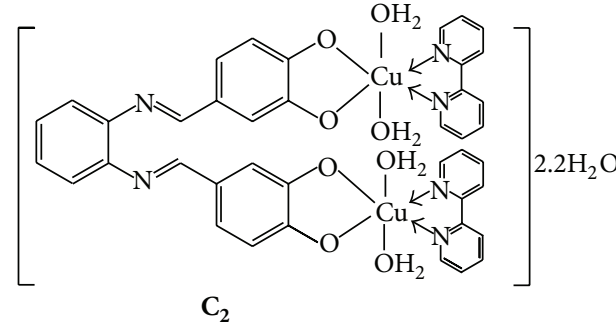

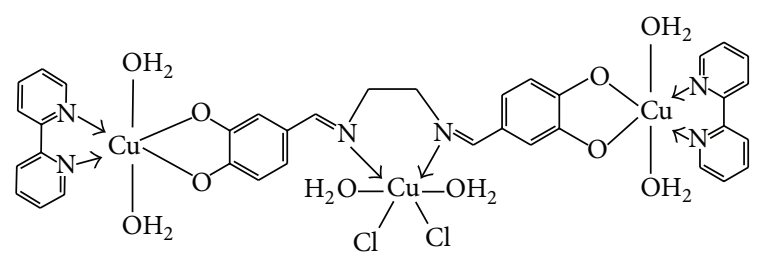

$\mathrm{C}_{4}$

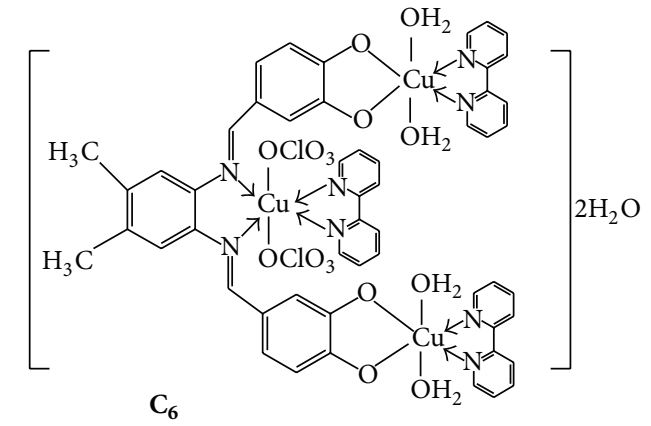

$\mathrm{X}=0\left(\mathbf{C}_{\mathbf{5}}\right) \quad \mathrm{X}=0.56 \mathrm{Et}_{3} \mathrm{~N}\left(\mathbf{C}_{\mathbf{1 4}}\right)$

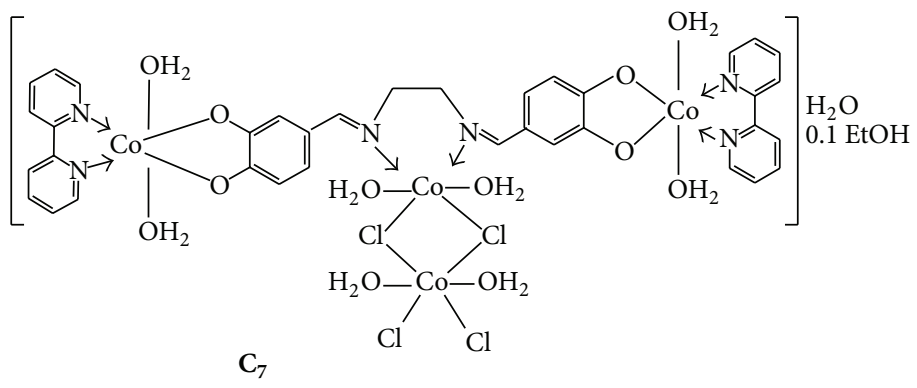

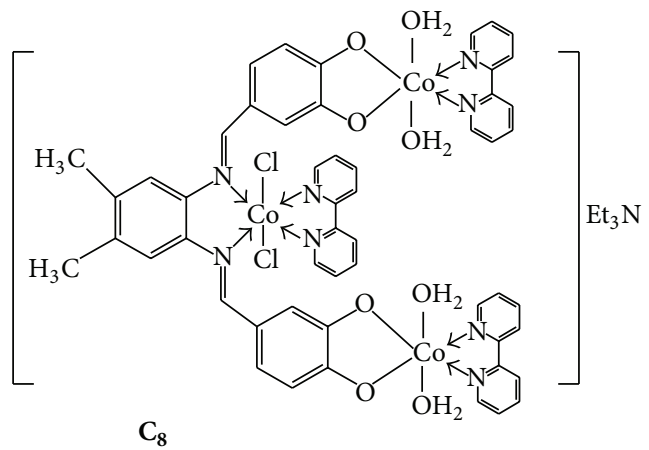

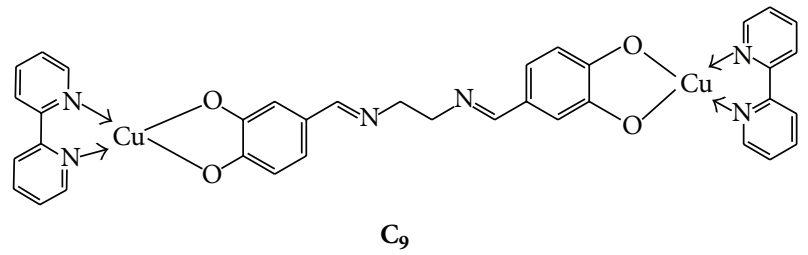




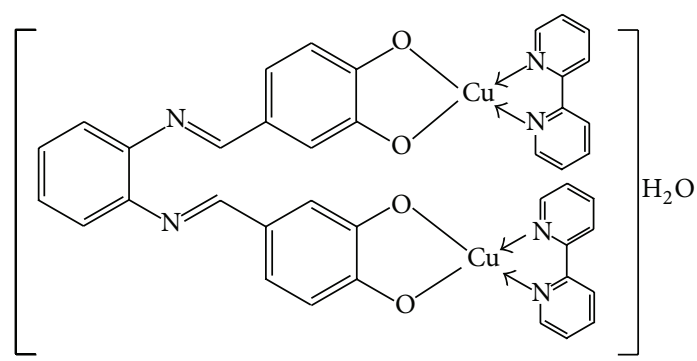

$\mathrm{C}_{10}$

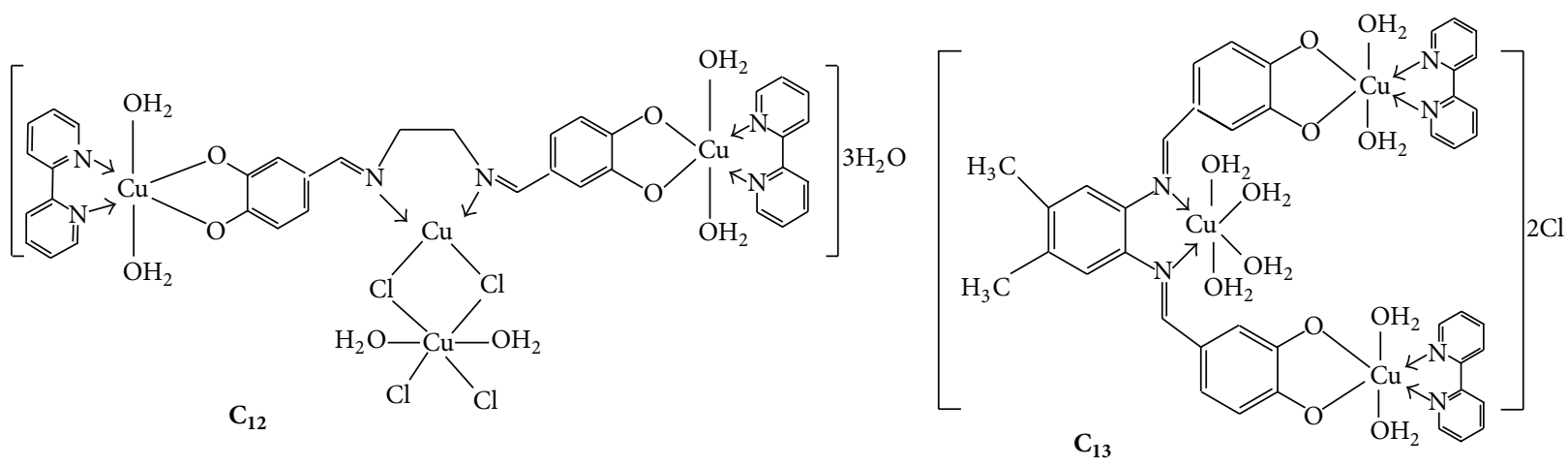

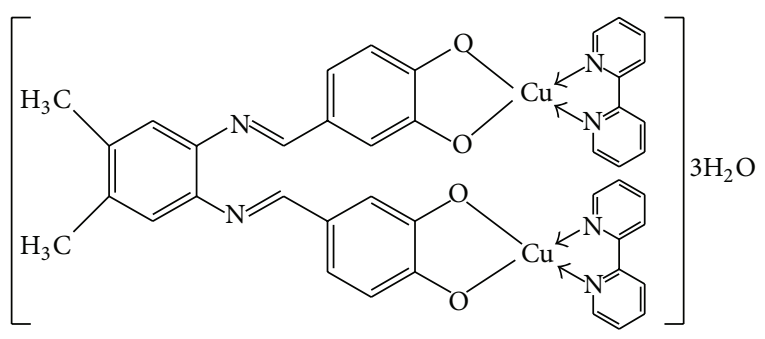

$\mathrm{C}_{11}$

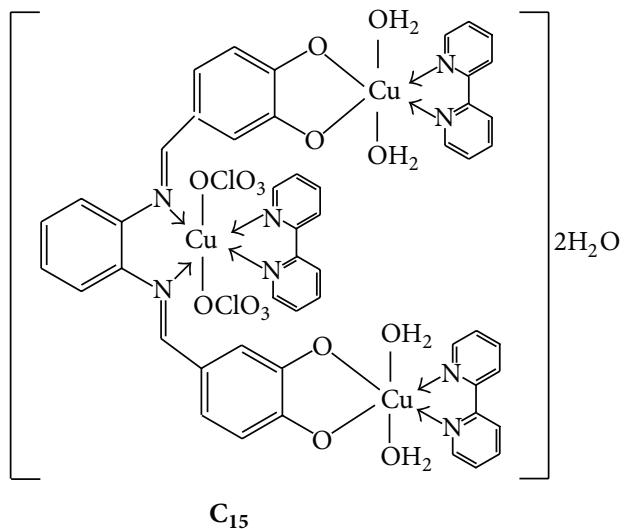

Scheme 2: Suggested stereochemical structures of the synthesized diSchiff base complexes.

residues at $1000^{\circ} \mathrm{C}$ indicates that the two complexes are very stable and require a higher temperature range for complete decomposition which is quite common for polynuclear metal complexes [5].

\section{Conclusions}

The bi-, tri-, and tetranuclear bis- and tris(bipyridyl) copper (II) and cobalt (II) mixed ligand complexes of three diSchiff base ligands derived from 3,4-dihydroxybenzaldehyde and three diamines in a stoichiometric ratio of $2: 1$ were successfully synthesized by two different methods. The structures of the ligands were confirmed by elemental and spectral analysis. Coordination of the metal ions to form trinuclear and tetranuclear complexes took place through the two imino nitrogens and phenolic dianionic oxygen atoms of each ligand molecule as was indicated by FTIR spectra. The formation of binuclear diSchiff base copper bis(bipyridyl) complexes was achieved by reacting the mononuclear copper (II) mixed ligand complex $\mathbf{C u L L}^{\prime}$ with the diamines in a 2:1 ratio, respectively, as was confirmed by the NMR spectrum of $\mathbf{C}_{11}$ while trinuclear bis- and tris(bipyridyl) and tetranuclear complexes of the three ligands were achieved by reacting the synthesized Schiff bases with the copper salts in the presence of $2,2^{\prime}$-bipyridyl. The complexes exhibited low values of magnetic moments which made them a good synthetic model for intramolecular antiferromagnetic spin exchange interaction of biological systems. In the future work the enzyme like and metalloprotein activities of these complexes and their biological activities will be studied in detail. 


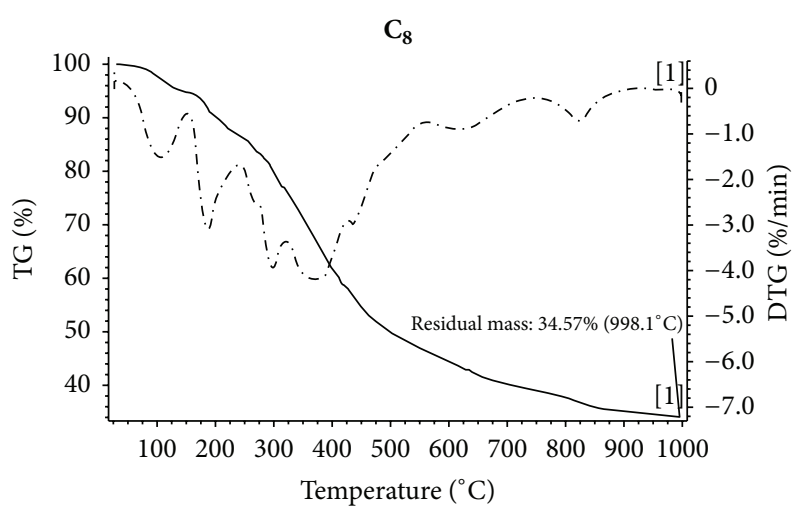

(a)

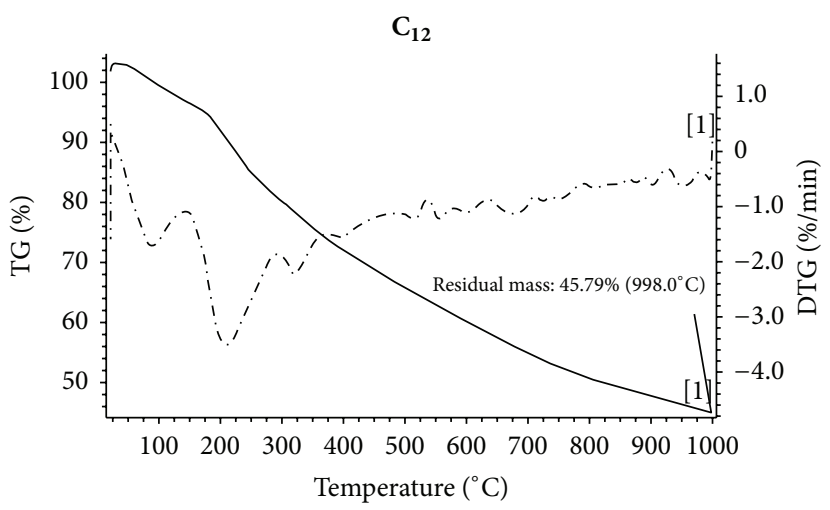

(b)

Figure 7: TG and DTG thermographs of $\mathbf{C}_{\mathbf{8}}$ and $\mathbf{C}_{\mathbf{1 2}}$.

TABLE 6: Thermal decomposition of the copper complexes $\left(\mathbf{C}_{8}\right.$ and $\mathrm{C}_{12}$ ).

\begin{tabular}{|c|c|c|}
\hline $\begin{array}{l}\mathrm{C}_{8} \text { stable phase } \\
{\left[\mathrm{MPD}\left(\mathrm{Co}_{3}(\text { bipy })_{3}\left(\mathrm{H}_{2} \mathrm{O}\right)_{4} \mathrm{Cl}_{2}\right] \mathrm{Et}_{3} \mathrm{~N}\right.} \\
\text { M.wt }=1260.7\end{array}$ & $\begin{array}{l}\text { Temp. range of } \\
\text { decomp. }{ }^{\circ} \mathrm{C}\end{array}$ & $\begin{array}{l}\text { Weight \% loss } \\
\text { found (calc.) }\end{array}$ \\
\hline$\downarrow 0.45 \mathrm{Et}_{3} \mathrm{~N}+\mathrm{Cl}+2 \mathrm{H}_{2} \mathrm{O}$ & $8-211$ & $9.00(9.28)$ \\
\hline$\downarrow 0.55 \mathrm{Et}_{3} \mathrm{~N}+2 \mathrm{H}_{2} \mathrm{O}$ & $212-423$ & $6.80(7.26)$ \\
\hline$\downarrow 2 \mathrm{CH}_{3}+2$ bipy $+\mathrm{C}_{6} \mathrm{H}_{2}$ & $424-661$ & $32.4(33.43)$ \\
\hline$\downarrow \mathrm{Cl}+$ bipy $+\mathrm{HCN}$ & $662-998$ & $17.23(17.33)$ \\
\hline $\begin{array}{l}\mathrm{C}_{7} \mathrm{H}_{4} \mathrm{NO}_{2} \mathrm{Co}_{2}+\mathrm{C}_{6} \mathrm{H}_{4} \mathrm{O}_{2} \mathrm{Co} \\
\text { (residue) }\end{array}$ & - & $34.57(33.13)$ \\
\hline $\begin{array}{l}\mathrm{C}_{12} \text { stable phase } \\
{\left[\mathrm{ED}\left(\mathrm{Cu}_{4}(\mathrm{bipy})_{2}\left(\mathrm{H}_{2} \mathrm{O}\right)_{6} \mathrm{Cl}_{4}\right] 3 \mathrm{H}_{2} \mathrm{O}\right.} \\
\text { M.wt }=1166.16\end{array}$ & $\begin{array}{l}\text { Temp. range of } \\
\text { decomp. }{ }^{\circ} \mathrm{C}\end{array}$ & $\begin{array}{l}\text { Weight } \% \text { loss } \\
\text { found (calc.) }\end{array}$ \\
\hline$\downarrow 4 \mathrm{H}_{2} \mathrm{O}$ & $73-26$ & $5.80(6.17)$ \\
\hline$\downarrow 5 \mathrm{H}_{2} \mathrm{O}+\mathrm{C}_{2} \mathrm{H}_{4}$ & $262-365$ & $10.20(10.11)$ \\
\hline$\downarrow \mathrm{C}_{5} \mathrm{H}_{4} \mathrm{~N}+$ bipy & $366-542$ & $20.00(19.46)$ \\
\hline$\downarrow 4 \mathrm{Cl}$ & $543-761$ & $11.8(12.13)$ \\
\hline$\downarrow \mathrm{C}_{5} \mathrm{H}_{4} \mathrm{~N}$ & $762-998$ & $6.4(6.68)$ \\
\hline $\mathrm{C}_{14} \mathrm{H}_{8} \mathrm{~N}_{2} \mathrm{O}_{4} \mathrm{Cu}_{4}$ (residue) & - & $45.79(44.76)$ \\
\hline
\end{tabular}

\section{Conflict of Interests}

The authors declare that there is no conflict of interests regarding the publication of this paper.

\section{References}

[1] S. Pal, A. K. Barik, S. Gupta et al., "Anion dependent formation of linear trinuclear mixed valance cobalt(III/II/III) complexes and mononuclear cobalt(III) complexes of a pyrazole derived ligand-synthesis, characterization and X-ray structures," Polyhedron, vol. 27, no. 1, pp. 357-365, 2008.

[2] N. Karaböcek, S. Karaböcek, and F. Kormali, "Mono-, diand trinuclear copper(II) complexes of a Schiff base ligand, 2-(E)-[(6-[(1E)-(2-hydroxyphenyl)methylene] aminopyridin2-yl)imino]-methyl phenol," Turkish Journal of Chemistry, vol. 31, no. 3, pp. 271-277, 2007.
[3] A. M. Nassar, A. M. Hassan, A. N. Elkmasha, and Y. Z. Ahmed, "Synthesis and characterization of novel binuclear complexes," International Journal of Chemical and Biochemical Sciences, vol. 2, pp. 83-93, 2012.

[4] A. M. Hassan, A. M. Nassar, Y. Z. Ahmed, and A. N. Elkmash, "Synthesis, characterization and biological evaluation, of binuclear $\mathrm{OF} \mathrm{Fe}(\mathrm{III}), \mathrm{Co}(\mathrm{II}), \mathrm{Ni}(\mathrm{II}), \mathrm{Cu}(\mathrm{II})$ and $\mathrm{Zn}(\mathrm{II})$ complexes with schiff base (E)-4-[(hydroxyl phenylimino)methyl]benzene-1, 2-diol," International Journal of Pharmaceutical Sciences and Research, vol. 3, no. 7, pp. 2243-2251, 2012.

[5] B. Dede, F. Karipcin, and M. Cengiz, "Synthesis, characterization and extraction studies of N,N" - Bis[1-biphenyl-2hydroxyimino-2-(4-acetylanilino)-1-ethylidene]-diamines and their homo-and heteronuclear copper(II) complexes," Journal of Chemical Sciences, vol. 121, no. 2, pp. 163-171, 2009.

[6] C. Lee and N. Jeong, "Synthesis of novel 3, 3'-dimethyl2, 2'-bipyridyl derivatives having nematic liquid-crystalline and photoluminescent properties," Journal of Industrial and Engineering Chemistry, vol. 8, no. 2, pp. 103-107, 2002.

[7] Y. Prashanthi, K. Kiranmai, Ira, K. Sathish kumar, V. K. Chityala, and Shivaraj, "Spectroscopic characterization and biological activity of mixed ligand complexes of $\mathrm{Ni}(\mathrm{II})$ with 1 , 10-phenanthroline and heterocyclic schiff bases," Bioinorganic Chemistry and Applications, vol. 2012, Article ID 948534, 8 pages, 2012.

[8] S. Z. Yildiz, M. N. Misir, N. Tüfekçi, and Y. Gök, "The synthesis and characterization of a novel (E,E)-dioxime and its monoand polynuclear complexes," Acta Chemica Scandinavica, vol. 52, no. 6, pp. 694-701, 1998.

[9] I. A. Vogel, Practical Organic Chemistry Qualitative Organic Analysis, Longman Group Limited, London, UK, 3rd edition, 1972.

[10] D. D. Perrin and W. L. F. Armarego, Purification of Laboratory Chemicals, Pergamon Press, London, UK, 2nd edition, 1980.

[11] K. V. Patel and P. K. Bhattacharya, "Study of some trinuclear copper(II) complexes involving catechol aldehyde and heteroaromatic nitrogen bases," Polyhedron, vol. 5, no. 3, pp. 731734, 1986.

[12] L. Fotouhi, S. Asadi, E. Tammari, M. M. Heravi, and D. Nematollahi, "Electrochemical oxidation of catechol and 4-tertbutylcatechol in the presence of 1-methyl-1H-imidazole-2-thiol: 
synthesis and kinetic study," Journal of the Iranian Chemical Society, vol. 5, no. 4, pp. 712-717, 2008.

[13] R. M. Silverstein and F. X. Webster, Spectrometric Identification of Organic Compounds, John Wiley and Sons, New York, NY, USA, 6th edition, 1997.

[14] S. Bayari, A. Ataç, and Ş. Yurdakul, "Coordination behaviour of nicotinamide: an infrared spectroscopic study," Journal of Molecular Structure, vol. 655, no. 1, pp. 163-170, 2003.

[15] K. Nakamoto, Infrared and Ramman Spectra of Inorganic and Coordination Compounds, John Wiley and Sons, New York, NY, USA, 5th edition, 1997.

[16] V. L. Chavan and B. H. Mehta, "X-ray, thermal and biological studies of $\mathrm{Ru}(\mathrm{III}), \mathrm{Rh}(\mathrm{III})$ and $\mathrm{Pd}(\mathrm{II})$ schiff base metal complexes," Research Journal of Chemistry and Environment, vol. 15, no. 2, pp. 57-61, 2011.

[17] M. A. Neelakantan, M. Esakkiammal, S. S. Mariappan, J. Dharmaraja, and T. Jeyakumar, "Synthesis, characterization and biocidal activities of some schiff base metal complexes," Indian Journal of Pharmaceutical Sciences, vol. 72, no. 2, pp. 216-222, 2010.

[18] M. Tumer, N. Deligonul, A. Golcu, E. Akgun, and M. Dolaz, "Mixed-ligand copper (II) complexes: investigation of their spectroscopic, catalysis, antimicrobial and potentiometric properties," Transition Metal Chemistry, vol. 31, no. 1, pp. 1-12, 2006.

[19] I. A. Mohammed and R. M. Hamidi, "Synthesis of new liquid crystalline diglycidyl ethers," Molecules, vol. 17, no. 1, pp. 645656, 2012.

[20] K. Mounika, B. Anupama, A. Pragathi, and C. Gyanakumari, "Synthesis and characterization and biological activity of schiff base derived from 3-ethoxy salicylaldehyde and 2-amino benzoic acid and its transition metal complexes," Journal of Scientific Research, vol. 2, no. 3, pp. 513-524, 2010.

[21] S.-T. Ha, Y.-F. Win, T.-M. Koh, and Y.-T. Chong, "Synthesis and characterization of 4-[(3-cyanophenyl)imino] methyl-3hydroxyphenyl octadecanoate," Australian Journal of Basic and Applied Sciences, vol. 5, no. 1, pp. 15-19, 2011.

[22] A. E. Sabic, M. Karabork, G. Ceyhan, M. Tumer, and M. Digrak, "Polydentate schiff base ligands and their la(III) complexes: synthesis, characterization, antibacterial, thermal and electrochemical properties," International Journal of Inorganic Chemistry, vol. 2012, Article ID 791219, 11 pages, 2012.

[23] A. B. P. Lever, Inorganic Electronic Spectroscopy, Elsevier, Amsterdam, The Netherlands, 1968.

[24] M. V. Angelusiu, G. L. Almajan, D. C. Ilies, T. Rosu, and $\mathrm{M}$. Negoiu, "Cu(II) complexes with nitrogen-oxygen donor ligands: synthesis and biological activity," Chem. Bull. "POLITEHNICA" University of Timisoara, vol. 53, no. 1-2, article 67, pp. 78-82, 2008.

[25] P. M. Reddy, R. Rohini, E. R. Krishna, A. Hu, and V. Ravinder, "Synthesis, spectral and antibacterial studies of copper(II) tetraaza macrocyclic complexes," International Journal of Molecular Sciences, vol. 13, no. 4, pp. 4982-4992, 2012.

[26] M. J. Al-Jeboori, A. J. Abdul-Ghani, and A. J. Al-Karawi, "Synthesis and structural studies of new mannich base ligands and their metal complexes," Transition Metal Chemistry, vol. 33, no. 7, pp. 925-930, 2008.

[27] A. M. N. Khaleel and A. J. Abdul-Ghani, "Synthesis and characterization of new schiff bases derived from $N$ (1)substituted isatin with dithiooxamide and their co(II), Ni(II), $\mathrm{Cu}(\mathrm{II}), \mathrm{Pd}(\mathrm{II})$, and $\mathrm{Pt}(\mathrm{IV})$ complexes," Bioinorganic Chemistry and Applications, vol. 2009, Article ID 413175, 12 pages, 2009.
[28] W. J. Geary, "The use of conductivity measurements in organic solvents for the characterisation of coordination compounds," Coordination Chemistry Reviews, vol. 7, no. 1, pp. 81-122, 1971. 

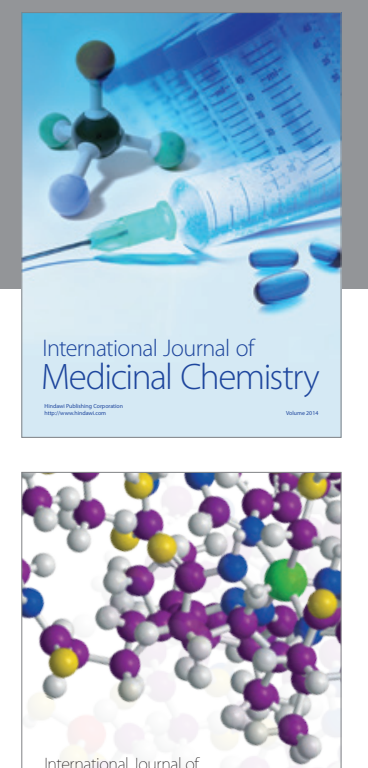

\section{Carbohydrate} Chemistry

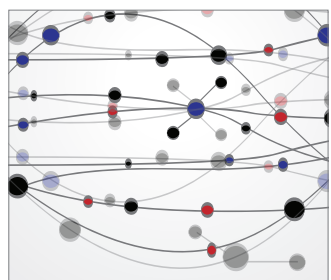

The Scientific World Journal
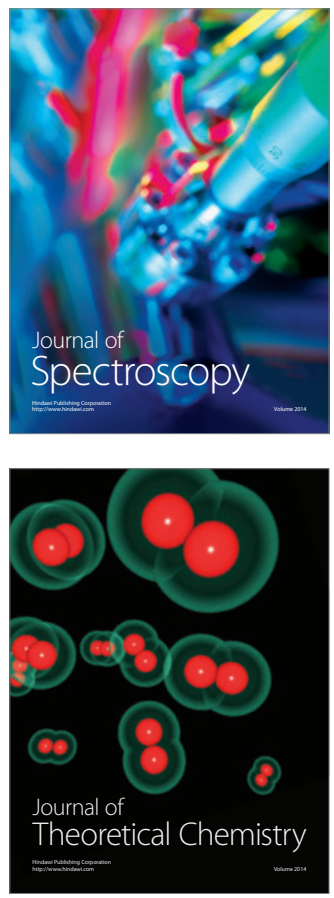
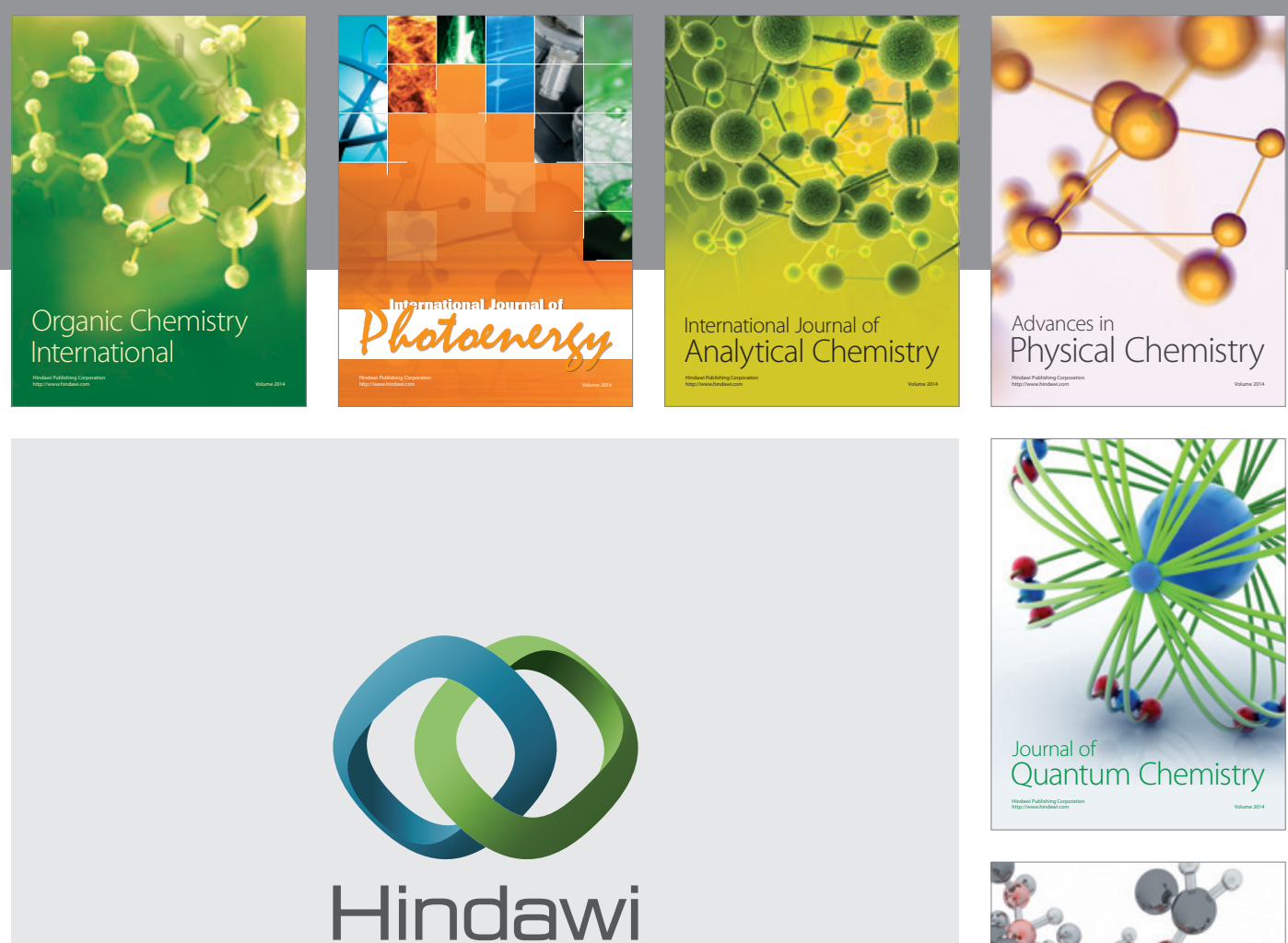

Submit your manuscripts at

http://www.hindawi.com

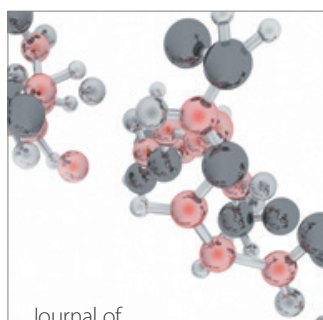

Analytical Methods

in Chemistry

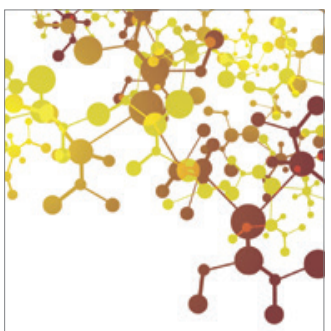

Journal of

Applied Chemistry

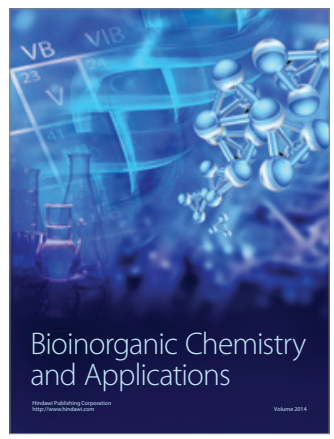

Inorganic Chemistry
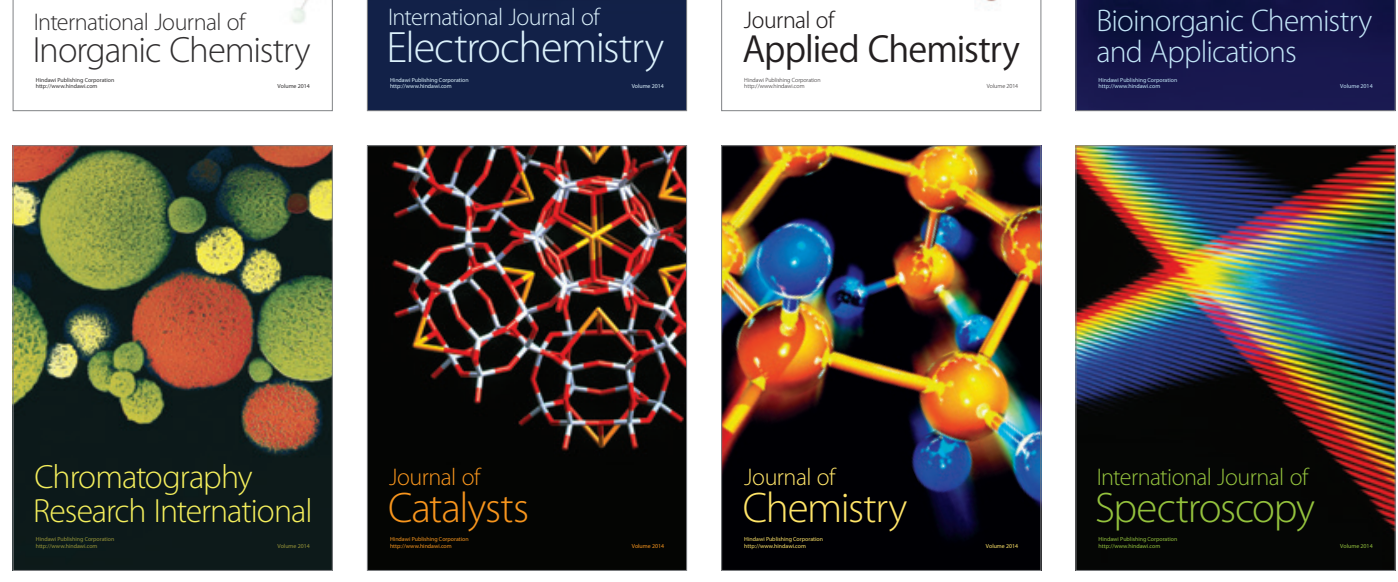